\title{
Synthesis and Characterization of Boron, Copper, and Zinc-Doped Hydroxyapatite by Sol-Gel Method: Research of Absorption and Thermal Behavior
}

Dilek Çanakçı ( $\sim$ dcanakci@adiyaman.edu.tr)

Adıyaman University

\section{Research Article}

Keywords: hydroxyapatites, Boron, Copper, Fourier transform infrared (FTIR)

Posted Date: January 14th, 2021

DOl: https://doi.org/10.21203/rs.3.rs-144127/v1

License: (c) (1) This work is licensed under a Creative Commons Attribution 4.0 International License.

Read Full License 


\section{Abstract}

In this study, hydroxyapatites reinforced with Boron, Copper and Zinc at different rates were produced using the sol-gel method. Different amounts of metal during the production of hydroxyapatite were used to observe the amount of crystallization and morphological differences in their structures. The characterization of the metal-doped HAp was carried out by X-ray diffraction (XRD), Fourier transform infrared (FTIR) spectroscopy, scanning electron microscopy (SEM) and Energy-dispersive X-ray spectroscopy (EDX). The data indicated that the $\mathrm{Ca} / \mathrm{P}$ stoichiometric ratios of the samples varied between 1.71 and 2, so their morphologies were different from each other. The absorption behavior of novel metal-doped HAp samples was evaluated at room temperature by UV-vis spectroscopy. In the absorption spectra of the samples, absorption bands formed in similar regions. In addition, the thermal behavior of HAp samples was investigated using TG/DTA techniques. The results of the analysis showed that heat resistance of the new synthesized samples was quite high.

\section{Introduction}

Bone is formed of an inorganic roof and an inorganic matrix that supports and regulates this roof. Inorganic roof of the bone is essentially formed of calcium and phosphate elements [1]. The smallest functional unit of the bone is called as osteon and when this structure is examined at electronmicroscopic level, it can be seen that the collagen fibers with a diameter of one micrometer combine together and form the bone layers (lamels) and the channel system. On these collagen fibers, hydroxyapatite crystals with a size of 100 nanometer are sequenced and form the microscopic structure of the bone [2]. Calcium hydroxyapatite $\left(\mathrm{HA}: \mathrm{Ca}_{10}\left(\mathrm{PO}_{4}\right)_{6}(\mathrm{OH})_{2}\right)$ and Tri-calcium phosphate (TCP: $\left.\mathrm{Ca}_{3}\left(\mathrm{PO}_{4}\right)_{2}\right)$ develop the inorganic phases of human bones and teeth. Calcium phosphate-based bioceramic prosthesis have started to be used in the treatment of the bone and tooth diseases in rates increasing recently throughout the world [3-6]. In medicine, synthetic hydroxyapatites have been used commonly due to their properties such as biocompatibility, bioactivity, and osteoconductivity. Besides its numerous positive features, synthetic hydroxyapatites have low mechanical resistance and weak reactivity with the existing bones. In addition, they cannot be used in a wide range of applications for load bearing applications. In order to eliminate such disadvantages, metal ions with different properties and rates are added to the structure of hydroxyapatite (Al, $\mathrm{Co}, \mathrm{Fe}, \mathrm{F}, \mathrm{Cl}, \mathrm{Sr}, \mathrm{Si}, \mathrm{Cu}, \mathrm{Cr}, \mathrm{Ba}, \mathrm{K}, \mathrm{Na}, \mathrm{Mg}, \mathrm{Zn}, \mathrm{Mn}, \mathrm{Cd}$, $\mathrm{Se}, \mathrm{Ni}, \mathrm{Ti}$, and $\mathrm{Y}$ ) [7-13].

Besides the use of HA as a powdered filling material in the body, it is also used in a sintered form. Significant changes occur in the mechanical property and stability of HA after the sintering process conducted to obtain resistance and a dense structure [14, 15]. When HA is exposed to a thermal process between 900 and $1200{ }^{\circ} \mathrm{C}$, changes occur in the Ca/P mol ratio in its structure. Slight deviations from $\mathrm{Ca} / \mathrm{P}$ ratio of $\mathrm{HA}$ which is 1.67 may cause the formation of other calcium phosphate phases during these processes (alpha, beta-tricalcium phosphate, tetra calcium phosphate) [16]. Such different phases occurring after sintering are affected by the $\mathrm{pH}$ changes in the body. 
Even though HA starts stable in the body without dissolution in the solutions with the $\mathrm{pH}$ values higher than $4.2 \mathrm{pH}$, as the $\mathrm{pH}$ value of TCP media increases, its stable structure is degraded and then absorbed by the body. This situation disadvantageous for TCP becomes an advantage if it is used as a synthetic bone material because bone growth occurs in the cavities forming due to dissolution after a while [17].

Today, various methods have been used in the production of synthetic HA. Examples can include PVD (physical vapor deposition), CVD (chemical vapor deposition), ion beam, laser, plasma spray, vacuum plasma, EPD (electrophoretic coating), HVOF (High velocity oxygen fuel thermal spray process), and solgel. All these methods have their own advantages and disadvantages. Sol-gel, one of the most preferred methods, is used to synthesize HAp due to high product purity at low temperatures and low cost [18-28]. In various studies, it is specified that the parameters such as temperature, period [29], acid addition rate, and precipitation drying rate [30] have significant effects on the particle size and morphology in the production of HA via chemical synthesis method. It is stated in the literature that some of the metal ions ( $\mathrm{Zn}, \mathrm{Ag}, \mathrm{Cu}, \mathrm{Mg}$ ) that are added into HA during the production stage have an effect on the mechanical properties and antibacterial activity of the material produced [31, 32]; especially the addition of boron (B) has an accelerating effect on the bone formation, and the apatite formation ability of B-doped HA samples is higher than those that do not contain $B[33,34]$.

In this study, the synthesis of five novel metal-doped hydroxyapatites by sol-gel method, using copper, zinc and boron as metal ions was investigated. The crystal structure and morphology of the obtained materials were shown using different spectroscopic methods. Also, thermal stabilities of novel materials were studied by using the TG-DTA techniques and their absorption behaviors were examined using UV-vis spectroscopy.

\section{Materials And Methods}

\subsection{Chemicals, Reagents, and Analysis}

All chemicals used in this study were of analytical grade and supplied by Merch and Sigma-Aldrich. Briefly, the starting reactants used in preparing metal-doped $\mathrm{HAp}$ were calcium nitrate $\left(\mathrm{Ca}\left(\mathrm{NO}_{3}\right)_{2} \cdot 4 \mathrm{H}_{2} \mathrm{O}\right)$, phosphorus pentoxide $\left(\mathrm{P}_{4} \mathrm{O}_{10}\right.$, Sigma-Aldrich), potassium dihydrogen phosphate $\left(\mathrm{KH}_{2} \mathrm{PO}_{4}, \mathrm{Merch}\right)$, sodium bicarbonate ( $\mathrm{NaHCOQ}$, Sigma-Aldrich), Copper(II)acetate $\left(\mathrm{Cu}\left(\mathrm{CO}_{2} \mathrm{CH}_{3}\right)_{2}\right.$, Merch) and Zinc(II)acetate $\left(\mathrm{Zn}\left(\mathrm{CO}_{2} \mathrm{CH}_{3}\right)_{2}\right.$, Merch).

The compounds used to synthesize schiff base monomer and polymer were 2-formylfuran-5-boronic acid $\left(\mathrm{C}_{5} \mathrm{H}_{5} \mathrm{BO}_{4}, \mathrm{Merch}\right), 6$-amino-m-cresol $\left(\mathrm{H}_{2} \mathrm{NC}_{6} \mathrm{H}_{3}\left(\mathrm{CH}_{3}\right) \mathrm{OH}\right.$, Merch), potassium hydroxide ( $\left.\mathrm{KOH}, \mathrm{Merch}\right)$, hydrochloric acid ( $\mathrm{HCl}, \mathrm{Merch})$, ethanol $\left(\mathrm{C}_{2} \mathrm{H}_{5} \mathrm{OH}\right.$, Merch), and Tetrahydrofuran (THF, Merch).

The presence of functional groups was analyzed by FTIR spectroscopy in the Perkin Elmer-Spectrum 100 FTIR instrument in the $400-4000 \mathrm{~cm}^{-1}$ range. ${ }^{1} \mathrm{H}-\mathrm{NMR}$ spectra of schiff base monomers and polymers were recorded on an Agilent $400 \mathrm{MHz}$ WB (Widebore) NMR instrument. 
Rigaku SmartLab X-ray diffractometer, having a copper (Cu) X-ray tube, at $40 \mathrm{kV}$ and $40 \mathrm{~mA}$, with a wavelength of $1.544 \AA$ and having Cu Ka X rays was used to characterize the crystallographic features of HAp powders. The surface morphology, elemental identification and quantitative composition of the prepared HAp were investigated by using a JEOL SEM 5300 scanning electron microscope.

Thermogravimetric (TGA) and differential thermal analyses (DTA) were carried out at a heating rate of 20 ${ }^{\circ} \mathrm{C} / \mathrm{min}$ in the range of $0-1100{ }^{\circ} \mathrm{C}$ under nitrogen atmosphere using a TA Instrument SDT 2960.

\subsection{Experiments}

\subsubsection{Synthesis of schiff base monomer}

The novel schiff base monomer was synthesized according to the following procedure:5-amino-1naphthol(3 mmol) and 3-formylfuran-5-boronic acid(3 mmol) were dissolved in ethanol/THF solvent mixture $(5 \mathrm{~mL} / 2 \mathrm{~mL})$. The reaction mixture was refluxed for $5 \mathrm{~h}$ at $80{ }^{\circ} \mathrm{C}$. At the end of the process, the solution was evaporated and the solvents were separated from the formed schiff base. The obtained powder was washed with cold ethanol and diethyl ether and dried under vacuum over. MSB: 5-(((5(dimethylboryl)furan-2-yl)methylene)amino)naphthalen-1-ol.

\subsubsection{Synthesis of schiff base polymer}

A solution containing 5-(((5-(dimethylboryl)furan-2-yl)methylene)amino)naphthalen-1-ol(2 mmol) in absolute ethanol $(10 \mathrm{~mL})$ was added $\mathrm{KOH}(2 \mathrm{mmol})$ solution (in water). The resulting mixture was then refluxed for 30 minutes at $70{ }^{\circ} \mathrm{C}$. In the next step, $\mathrm{NaOCl}$ was added dropwise into the mixture, the temperature was raised to $110^{\circ} \mathrm{C}$, and stirring was continued for 6 hours. After cooling to room temperature, polymers were precipitated by adding $\mathrm{HCl}(35 \%, 0.5 \mathrm{ml})$ into the dark colored mixture. The black polymer formed was filtered, washed with water to remove the salt from the medium, and dried at room temperature [35]. (PSB: 5-((5-(dimethylboryl)furan-2-yl)methylene)amino)naphthalen-1-ol) Figure 1.

\subsubsection{Preparation of novel metal-doped HAp}

The sol-gel method was used to produce HAp and its production steps were realized as follows: to prepare the starting solution, $45.10^{-2}$ moles of $\mathrm{Ca}\left(\mathrm{NO}_{3}\right)_{2} \cdot 4 \mathrm{H}_{2} \mathrm{O}, 2.10^{-2}$ moles of $\mathrm{KH} 2 \mathrm{PO} 4$ and $2.10^{-2}$ moles of $\mathrm{NaHCO} \otimes$ were stirred in $20 \mathrm{~mL}$ of ethanol until a homogeneous mixture was obtained. The ethanol solution containing PSB, $\mathrm{Cu}\left(\mathrm{CH}_{3} \mathrm{CO}_{2}\right)_{2}$ and $\mathrm{Zn}\left(\mathrm{CH}_{3} \mathrm{CO}_{2}\right)_{2}$ in different rates was added into the current solution. Afterwards, the solution of $\mathrm{P}_{4} \mathrm{O}_{10}\left(1.10^{-2} \mathrm{~mol}, 5 \mathrm{~mL} \mathrm{H} 2 \mathrm{O}\right)$ was added into the homogeneous solution and stirring was continued for 10 minutes. The $\mathrm{pH}$ of the mixture containing all components was kept between 6-7 using ammonia. The $\mathrm{pH}$ adjusted solution was first refluxed at room temperature for 1 hour and then at $50{ }^{\circ} \mathrm{C}$ for 1 hour. The resulting gel was subjected to aging process by being kept at room temperature for 24 hours. It was dried in the oven at $105^{\circ} \mathrm{C}$ for 12 hours. In the last step, the dried mixture was calcined at $1100^{\circ} \mathrm{C}$ for 3 hours (Figure 2).

\section{Results And Discussion}




\subsection{Characterization of monomer and polymer}

Figure 3 shows the FT-IR spectra of the synthesized compounds ( $\mathrm{Sb}$ and PSb). In the monomer spectrum $(\mathrm{Sb})$, the broad and middle peak at $3327 \mathrm{~cm}^{-1}$ formed as a result of the overlap of the stress vibrations of $-\mathrm{OH}$ groups in the structure of boric acid and naphthol. The weak shoulder peaks forming in the range $2968-2921 \mathrm{~cm}^{-1}$ near the $-\mathrm{OH}$ peak indicated the $\mathrm{C}-\mathrm{H}$ stretching vibrations of the aromatic rings of the monomer. The presence of the characteristic sharp peaks at $1611 \mathrm{~cm}^{-1}$ and $1579 \mathrm{~cm}^{-1}$ was identified as the symmetric vibrations of the schiff base group $\mathrm{C}=\mathrm{N}$ and aromatic $\mathrm{C}=\mathrm{C}$. The $\mathrm{O}-\mathrm{H}$ bending and $\mathrm{C}-\mathrm{O}$ stretching vibrations were found around $1379 \mathrm{~cm}^{-1}$ and $1207 \mathrm{~cm}^{-1}$, respectively [35].

The spectrum of polymer showed a very wide band in the range of $3700 \mathrm{~cm}^{-1}$ to $1900 \mathrm{~cm}^{-1}$ as a result of $-\mathrm{OH}$ and aromatic $\mathrm{C}-\mathrm{H}$ stretching vibrations. This is because there are too many repeating units in the structure of the polymer and the groups belonging to these units vibrate at the same time. The increased number of groups in the polymer structure caused the peaks to overlap and their number to decrease. Broad peaks formed in other groups in the structure. The peak observed between $1500 \mathrm{~cm}^{-1}$ and 1700 $\mathrm{cm}^{-1}$ formed as a result of overlapping of $\mathrm{C}=\mathrm{N}$ and $\mathrm{C}=\mathrm{C}$ stretching vibrations [35].

The single peak at $7.94 \mathrm{ppm}$ proved the presence of the proton of the imine group $(-\mathrm{CH}=\mathrm{N}-)$. Singlet and doublet peaks occurring in the range of 7.81-7.14 ppm were caused by naphthol and furan ring protons (Figure 4). The naphthol proton peak formed very weakly in the spectrum of the polymer. This is because $-\mathrm{OH}$ group contributes in polymerization more than the benzene ring (Figure 5). In the spectra of PSb, the two singlet peaks at 10.47 and $10.06 \mathrm{ppm}$ belonged to the $-\mathrm{OH}$ proton of boric acid. The imine proton of PSb was observed in the range of 8.12-7.84 ppm as multiplet. In addition, the multiple, doublet and singlet peaks in the range 7.53-5.86 ppm belonged to aromatic protons [35].

Gel permeation chromatography (GPC) was used to determine the molecular weight (Mn and $\mathrm{Mw}$ ) and polydispersity index (PDI) of the polymer (PSb). The values obtained for PSb were Mn:4.938, Mw: 5.864, and PDI:1.18. According to the obtained results, PSb formed by bonding of about 20 monomers.

\subsection{FT-IR spectroscopy}

The FT-IR spectroscopy was used to determine the functional groups of the newly synthesized HAp samples with metal at different rates. The spectra of the examples are given in figure 6 . In the samples

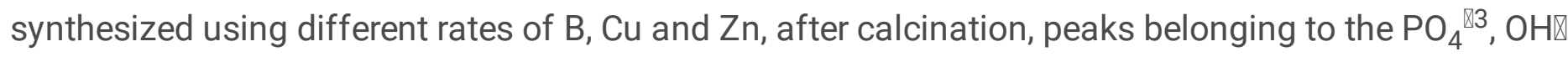
and $\mathrm{CO}_{3}{ }^{-2}$ functional groups as well as the peaks of the oxide bonds of the added metals were observed. The most distinctive difference observed in the spectra of the HAp samples is that the intensity of the peaks and their positions changed in proportion to the change in metal rates in the samples. One of the common features of FT-IR spectra of HAp samples was that the vibration peak of the $\mathrm{CO}_{3}{ }^{-2}\left(\mathrm{v}_{3}\right)$ group, which should be observed around $1450-1600 \mathrm{~cm}^{-1}$, did not form in any spectrum. But peaks around 2000 $\mathrm{cm}^{-1}$ indicated that there was $\mathrm{CO}_{3}^{-2}$ absorbed in the HAp structure. In addition, very weak peaks around 
$870 \mathrm{~cm}^{-1}$ supported the presence of $\mathrm{CO}_{3}^{-2}\left(\mathrm{v}_{2}\right)$. This is because the presence of different metals in the structure changed the position of the $\mathrm{CO}_{3}^{-2}$ group in the crystalline structure [36]. Two types of carbonate substitution are possible in hydroxyapatite. The first is the direct substitution of $\mathrm{OH} \rrbracket$ by $\mathrm{CO}_{3}{ }^{-2}$ (A-type substitution $\mathrm{CO}_{3}{ }^{-2} \leftrightarrow 2 \mathrm{OH} \mathbb{}$ ) and the second is charge compensation, $\mathrm{PO}_{4}{ }^{3-}$ substituting tetrahedral group with $\mathrm{CO}_{3}{ }^{-2}$ (B-type substitution). The proof of the formation of both $\mathrm{A}$ and $\mathrm{B}$ type carbonate substitutions in the synthesized novel metal- doped hydroxyapatites is seen in their spectra [37].

The wide and weak peaks observed at $3422 \mathrm{~cm}^{-1}$ in the HAp-B $B_{1}$ spectrum formed as a result of the stretching vibrations of the water absorbed by the sample. The peaks forming at 1985 and $1934 \mathrm{~cm}^{-1}$ indicated the presence of $\mathrm{CO}_{3}^{-2}$ absorbed in the structure. Vibration peaks of the apatite phase of sample

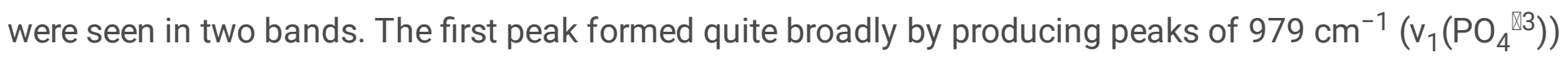

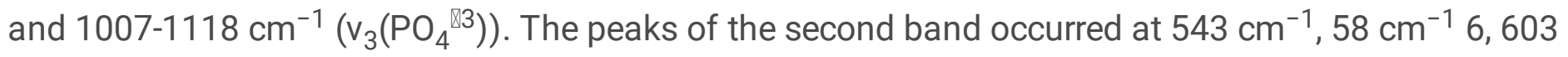

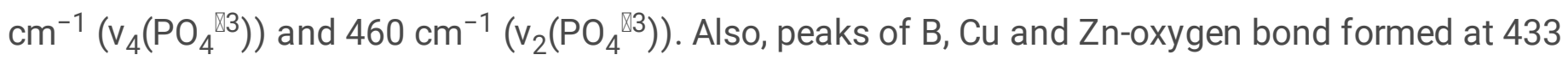
$\mathrm{cm}^{-1}, 396 \mathrm{~cm}^{-1}$, and $356 \mathrm{~cm}^{-1}$.

When the spectra of $H A p-B_{2}$ and $H A p-B_{1}$ were compared, it was observed that the peaks of the phosphate group formed more sharply. In addition, the locations of the stretching vibration peaks of both absorbed water and carbonate shifted and formed at $3007 \mathrm{~cm}^{-1}$ and $2005 \mathrm{~cm}^{-1}$. The addition of metal to the

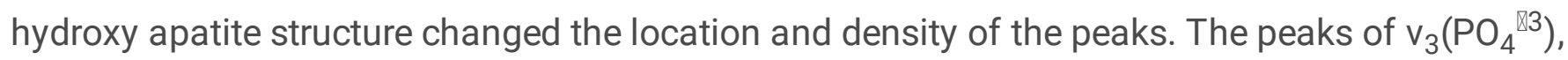

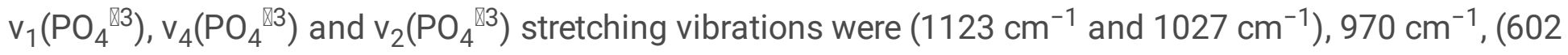
$\mathrm{cm}^{-1}$ and $552 \mathrm{~cm}^{-1}$ ) and 459 , respectively. A weak peak of the carbonate group was observed at 880 $\mathrm{cm}^{-1}$. Metal-oxygen bond peaks formed at $378 \mathrm{~cm}^{-1}, 366 \mathrm{~cm}^{-1}$ and $359 \mathrm{~cm}^{-1}$.

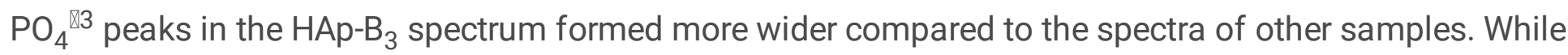
peaks at $\left(1123 \mathrm{~cm}^{-1}, 1011 \mathrm{~cm}^{-1}\right)$ and $970 \mathrm{~cm}^{-1}$ formed as a result of $\mathrm{v}_{3}\left(\mathrm{PO}_{4}{ }^{\circledR 3}\right)$ and $\mathrm{v}_{1}\left(\mathrm{PO}_{4}{ }^{\circledR 3}\right)$ stretching

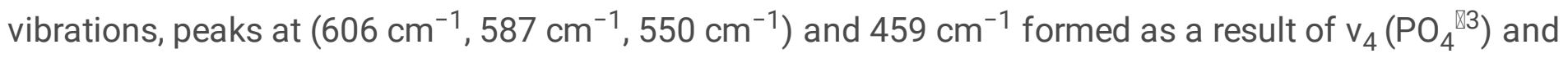
$\mathrm{v}_{2}\left(\mathrm{PO}_{4}{ }^{\otimes 3}\right)$ stretching vibrations. The absorbed water and carbonate peaks occurred at $2966 \mathrm{~cm}^{-1}$ and $2004 \mathrm{~cm}^{-1}$ in the spectrum. The other carbonate $\left(\mathrm{v}_{2}\left(\mathrm{CO}_{3}{ }^{-2}\right)\right)$ peak appeared in a very weak form at 864 $\mathrm{cm}^{-1}$. However, the peaks formed at $359 \mathrm{~cm}^{-1}, 366 \mathrm{~cm}^{-1}$ and $355 \mathrm{~cm}^{-1}$ as a result of metal-oxygen bond

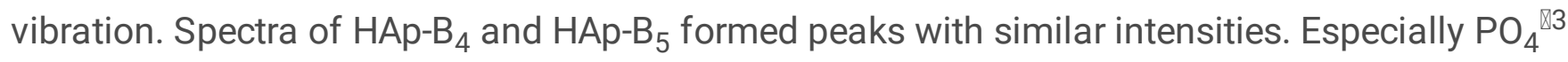

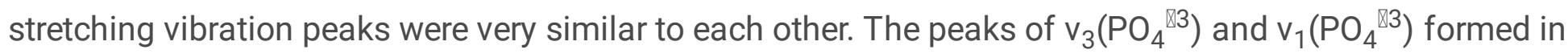
the range of $1123-968 \mathrm{~cm}^{-1}$ for $\mathrm{HAp}-\mathrm{B}_{4}$ and $1124-968 \mathrm{~cm}^{-1}$ for $\mathrm{HAp}-\mathrm{B}_{5}$. The $\mathrm{v}_{4}\left(\mathrm{PO}_{4}{ }^{\mathbb{2}}\right)$ stretching vibration

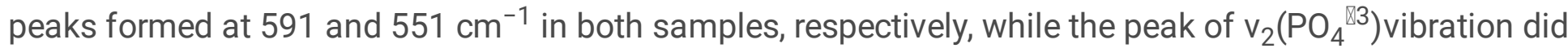
not occur. Another peak not seen in the spectra belonged to $\mathrm{v}_{2}\left(\mathrm{CO}_{3}{ }^{-2}\right)$. The peaks of absorbed water and carbonate formed at $3075 \mathrm{~cm}^{-1}$ for HAp-B, $2934 \mathrm{~cm}^{-1}$ for HAp-B ${ }_{5}$ and $1995 \mathrm{~cm}^{-1}$ for HAp-B ${ }_{4}$, and 1985 $\mathrm{cm}^{-1}$ for HAp-B ${ }_{5}$, respectively. Metal-oxygen bond vibration peaks formed in the range of $387-359 \mathrm{~cm}^{-1}$. 


\subsection{X-ray diffraction}

Figure 7- Figure 9 are XRD patterns of the synthesized powders. According to the XRD results, it was observed that all the XRD models had characteristic peaks that were consistent with International Center for Diffraction Data (ICDD) files that are valid for calcium phosphates. As a result of the XRD analysis, $2 \theta$ angle values were seen that are characteristic for $\mathrm{HAp}, \beta-\mathrm{TCP}, \mathrm{B}_{4} \mathrm{C}, \mathrm{B} 6 \mathrm{O}, \mathrm{CuO}$ and $\mathrm{ZnO}$ in the structure of HAp that is produced. As seen in the XRD patterns, main phase of the samples was $\beta$-TCP. Changes were observed in the $2 \theta$ values and intensities according to the addition rates of copper and zinc. The intensity and model of relevant peaks are expected to be changed according to the relative composition rate of $\mathrm{HA} / \beta-\mathrm{TCP}$ and the metal addition amount.

XRD pattern of $\mathrm{HAp} / \mathrm{B}_{1}$ showed peaks that appeared quite crystalline in the $10-90$ degree range, proving that the structure formed in HAp and $\beta$-TCP. XRD pattern of HAp/B 1 (HA/ $\beta-T C P)$ shows main peaks corresponding to HAp (JCPDS no. 09-0432) and $\beta$-TCP (JCPDS no. 09-169) in accordance to ICDD standard. The major diffraction peaks identified for HAp were in agreement with the standard JCPDS as a hydroxyapatite. Major sharp and intense peaks were observed at $2 \theta$ values of $25.8^{\circ}, 31.9^{\circ}$ and $32.5^{\circ}$. For $\beta$-TCP, the main peaks were indexed at $25.8^{\circ}, 26.7^{\circ}, 29.8^{\circ}, 31.1^{\circ}, 32.6^{\circ}$, and $34.5^{\circ}$.

The reason for the HAp/B ${ }_{1}$ powder to peak up to 90 degrees in the XRD model was the use of boron containing polymer in the production of hydroxyapatite. The presence of boron in the composition of the $\mathrm{HAp} / \mathrm{B}_{1}$ powder changed the peak intensities of HAp and $\beta$-TCP. In XRD patterns, the peaks observed at $2 \theta=14.2^{\circ}, 23.4^{\circ}, 33.6^{\circ}, 37.8^{\circ}$, and $41.9^{\circ}$ and all observed peaks between $70^{\circ}$ and $90^{\circ}$ were characteristic peaks of $\mathrm{B}_{6} \mathrm{O}$ (JCPDS file No: 01-080-2254). In addition, the peaks forming at $2 \theta=23.4^{\circ}, 35.6^{\circ}, 61.3^{\circ}, 62^{\circ}$, and $66.9^{\circ}$ prove the existence of $\mathrm{B}_{4} \mathrm{C}$ (JCPDS file No: 00-035-0798).

In the XRD pattern of $\mathrm{HAp} / \mathrm{B}_{2}, 54$ peaks proving that the main structure consisted of $\mathrm{HAp}$ and $\beta$-TCP formed in the range of $2 \theta=10^{\circ}-60^{\circ}$. Furthermore, new peaks formed indicating the presence of metal oxides in this range, while the number of peaks beyond $60^{\circ}$ proved that the presence of copper, zinc, and boron oxides decreased. The peak having the highest intensity and proving the presence of HAp/ $\beta$-TCP occurred at $2 \theta=31.2^{\circ}$ and $27.9^{\circ}$ adjacent to the nearby peaks. The peak observed at $35.2^{\circ}$ position with (111) indicated that the $\mathrm{HAp} / \mathrm{B}_{2}$ contained copper oxide as crystalline, which was in a good agreement with JCPDS card number 45-0937. In addition, the peaks observed at $56.9^{\circ}, 59.8^{\circ} 62.8$ and $66.3^{\circ}$ belonged to copper oxide. Also, the peaks of XRD pattern at $2 \theta=31.7^{\circ}, 47.5^{\circ}, 56.9^{\circ}, 62.8^{\circ}, 68.8^{\circ}$, and $76.7^{\circ}$ proved the presence of $\mathrm{ZnO}$ (JCPDS file No: 36-1451). The peaks of $\mathrm{B}_{6} \mathrm{O}$ were observed at $2 \theta=$ $14.3^{\circ}, 23.4^{\circ}, 33.6^{\circ}, 37.8^{\circ}, 41.9^{\circ}, 54.7^{\circ}, 56.6^{\circ}, 65.6^{\circ}$. Also, the peaks of $B_{4} C$ observed at $2 \theta=22^{\circ}, 35.7^{\circ}$.

The XRD result of $H A p / B_{3}$ showed that the crystal structure of $H A p / B_{3}$ powder was slightly different from both $H A p / B_{1}$ and $H A p / B_{2}$. The change in the rates of copper and zinc in the powder structure caused the formation of a more crystalline structure. The range of peaks was 10-100, unlike the other two powder samples. Especially, the intensity of the peaks after 60 degrees increased. The top five peaks with the 
highest density $\left(2 \theta=27.9^{\circ}, 31.2^{\circ}, 31.5^{\circ}, 34.5^{\circ}\right.$, and $\left.35.3^{\circ}\right)$ clearly showed the presence of HAp and $\beta$-TCP. The peaks forming at $2 \theta=14.2^{\circ}, 33.6^{\circ}, 41.9^{\circ}, 54.7^{\circ}, 56.4^{\circ}, 65.6^{\circ}$ belonged to $\mathrm{B}_{6} \mathrm{O}$ and the peaks forming at $2 \theta=22.1^{\circ}, 35.8^{\circ}$, and $37.5^{\circ}$ belonged to $B_{4} C$. Further, peaks of copper and zinc oxides formed at $2 \theta=$ $32.6^{\circ}, 36.7^{\circ}, 38.8^{\circ}, 47.0^{\circ}, 48.6^{\circ}, 53.2^{\circ}, 56.9^{\circ}, 57.6^{\circ}$, and $61.0^{\circ}$.

Based on the XRD result of $\mathrm{HAp} / \mathrm{B}_{4}$ and $\mathrm{HAp} / \mathrm{B}_{5}$, the peak intensities decreased and increased due to the change in metal content. Especially, the intensity of $\mathrm{HAp} / \mathrm{B}_{5}$ peaks decreased. Peaks proving the presence of HAp, $\beta-T C P$, and metal oxides $(B, C u, Z n)$ formed in the XRD data of both compounds.

The average particle size of HAp/B ${ }_{1-5}$ powders was calculated using the "Scherrer" equation (Eq.1)

$\mathrm{D}=(k \lambda) /(\beta \mathrm{D} \cos \theta)(1)$

D is Crystal size $(n m), \lambda$ is the wavelength of CuKa1 radiation (1.5406 $\AA$ ), $\beta$ is the full width at half maximum for the diffraction peak under consideration, $\theta$ is half value of the diffraction angle of the most severe peak (20/2), and $k$ is dimensionless shape factor. The particle size was calculated for highest intensity peak of $\mathrm{HAp} / \mathrm{B}_{1}, \mathrm{HAp} / \mathrm{B}_{2}, \mathrm{HAp} / \mathrm{B}_{3}, \mathrm{HAp} / \mathrm{B}_{4}$ and $\mathrm{HAp} / \mathrm{B}_{5}$, and the average of particle sizes was found to be $88 \mathrm{~nm}, 69 \mathrm{~nm}, 95 \mathrm{~nm}, 84 \mathrm{~nm}$, and $70 \mathrm{~nm}$, respectively.

On the other hand, the fraction of the crystalline phase of hydroxyapatite in the samples (Xc) was calculated using the (Eq.2)

$X c=100 x((I b-V a / b) / / b)(2)$

where $X_{c}$ is the fraction of crystalline phase, $\mathrm{lb}$ is the highest intensity of diffraction peak, and $\mathrm{Va} / \mathrm{b}$ is the intensity of the trough between the lowest and highest diffraction peaks. The specific surface area was calculated with the formula(Eq.3)

Ssp $=6 \times 103 / d \times$ pth (3)

where $d$ is the average particle diameter and the theoretical density of the hydroxyapatite is pth (HAP) $=$ $3.16 \mathrm{~g} / \mathrm{cm}^{3}$ for spherical particles. Table 1 shows the calculated fraction of the crystalline phase and specific surface area values. The crystal phase fraction of metal-doped hydroxyapatite powders is quite high as expected. The highest crystal phase fraction belonged to $H A p / B_{2}(99 \%)$ and the lowest crystal phase fraction belonged to $\mathrm{HAp} / \mathrm{B}_{5}(93 \%)$. The specific area of metal-doped powders was between 19.98 and $27.51 \mathrm{~m}^{2} / \mathrm{g}$ and different specific area values were obtained from each other due to the varying metal rates in the powders.

\subsection{Morphological Investigations}

Scanning electron microscopy images were used to show the surface morphology of the metal-doped HAp powders obtained and EDX spectra were taken for quantitative element analysis of the imaged regions. SEM images revealed that all powder samples had a different agglomerated spherical and 
granular morphology, due to the difference in metal content in the structure even when calcined at the same temperature. Differentiation of the morphology of the powders increased especially with the addition of $\mathrm{Cu}$ and $\mathrm{Zn}$ elements to their structures.

Macrostructure and microstructure SEM images obtained at different magnifications showed that $\mathrm{HAp} / \mathrm{B}_{1}$ and $\mathrm{HAp} / \mathrm{B}_{2}$ were quite different from $\mathrm{HAp} / \mathrm{B}_{3}, \mathrm{HAp} / \mathrm{B}_{4}$ and $\mathrm{HAp} / \mathrm{B}_{5}$ in terms of roughness, pore size, geometry, and total porosity. Powder samples were compact, also had both micro and macroporosity and were not interconnected.

If the powder samples were compared in terms of porosity, it was observed that the best porous structure formed in $H A p / B_{1}$ and $H A p / B_{2}$ (Figure 10,11). The presence of pores of different sizes in the morphology of these samples indicated that they can initiate an inflammatory process similar to the early phase of fracture healing when applied to the tissue, as in almost all artificial bone tissue ceramics of mineral origin, depending on their porosity (17).

The similarity in the morphology of $\mathrm{HAp} / \mathrm{B}_{3}, \mathrm{HAp} / \mathrm{B}_{4}$ and $\mathrm{HAp} / \mathrm{B}_{5}$ powders is that they created smooth structures with little pore structure (Figure $12,13,14$ ). A layered structure formed on the surface of all three powder samples. In addition, there were particles independent of the matrix structure and differently crystallized depression in their surfaces. The main reason for this formation was formation of metaloxygen bond in the hydroxy apatite structure, which is degraded by the effect of high temperature, regardless of the difference in metal rates. This bond indicated the presence of both metal oxides and metal-phosphate bonds.

Although the data obtained from the EDX analysis showed that the expected elements (Ca, P, O, C, B, Cu, $\mathrm{Zn}, \mathrm{K}$ ) were present in the prepared powder samples (Figure 15, 16). The data revealed that the Ca:P ratio was $1.86,2,1.90,1.71$ and 1.87 for $\mathrm{HAp} / \mathrm{B}_{1}, \mathrm{HAp} / \mathrm{B}_{2}, \mathrm{HAp} / \mathrm{B}_{3}, \mathrm{HAp} / \mathrm{B}_{4}$ and $\mathrm{HAp} / \mathrm{B}_{5}$, respectively, which was not very close to the ideal value of 1.67 normally associated with HAP. When HAp is exposed to high temperatures $\left(900-1200^{\circ} \mathrm{C}\right)$, there is degradation at the $\mathrm{Ca} / \mathrm{P}$ mol ratio in its structure. In particular, adding different metal ions to the hydroxyapatite structure causes this ratio to be different than expected. The deviations of HA from the Ca/P ratio of 1.67 may cause the formation of other calcium phosphate phases (alpha, beta-tricalcium phosphate, tetra calcium phosphate) during these processes.

In addition, Apatite has a chemical structure that allows it to be replaced with other ions. Due to this

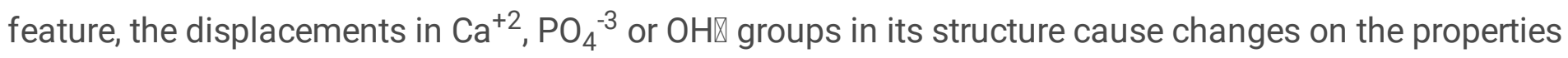
of its substance. EDX analysis results showed that the addition of $\mathrm{B}, \mathrm{Cu}$ and $\mathrm{Zn}$ ions at different rates into the structures of newly prepared hydroxyapatite powders caused a different morphological structure than expected. This difference in powder structure is an expected situation and show parallelism with the main purpose of this study.

\subsection{UV-Visible spectroscopy}


Figure 17 shows the UV-vis spectra of the novel HAp powders. Due to similar element contents, the samples formed absorption bands in same regions. The absorption bands were formed by the interaction of calcium phosphate and metal oxides with photons. When metals interact with photons, they can form different electron transitions. These transitions are usually ligand-metal charge transfer (LMCT) and d-d transitions. These transitions can include the metal ion itself or its ligand or ions binding to the metal ion. All synthesized HAp powders did not show absorption in the spectral range of $400-700 \mathrm{~nm}$. This is because the samples had a d-d transition instead of the LMCT transition. While HAp/B $1, H A p / B_{2}, H A p / B_{5}$

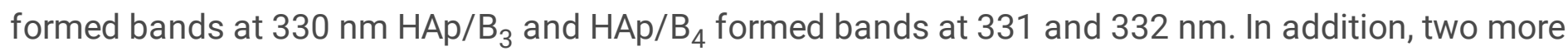
peaks were observed at 304 and $301 \mathrm{~nm}$ for HAp/B ${ }_{1}$, at 305 and $273 \mathrm{~nm}$ for HAp/B ${ }_{2}$ and at 305 and 296 $\mathrm{nm}$ for $\mathrm{HAp} / \mathrm{B}_{5}$. These peaks seen in the spectrum formed as a result of charge transfer between oxygen and metal ions.

\subsection{TGA analysis}

The thermal properties of the prepared metal doped HAp powders were determined by thermogravimetric analysis (TGA) and differential thermal analysis (DTA) method in a nitrogen atmosphere heated at 20 ${ }^{\circ} \mathrm{C} / \mathrm{min}$. in the range of $0{ }^{\circ} \mathrm{C}-1150{ }^{\circ} \mathrm{C}$. Figure 18 and figure 19 show the TGA and DTA thermograms of prepared powders. From the TGA result of the powders, it can be seen that there was no phase transformation as a result of heating, thus indicated that the novel metal-doped hydroxyapatites had thermal stability at high temperatures.

The observed initial mass loss in the region of $20-200{ }^{\circ} \mathrm{C}$ can be due to the dehydroxylation of hydroxyapatite powders. There was no significant loss of mass for all powders during the thermal decomposition process. The main reason for this was $\mathrm{B}, \mathrm{Cu}$ and $\mathrm{Zn}$ compounds in the structure of powders. Metals have high temperature resistance. Especially boron is very stable against temperature changes and today boron is used in the production of many materials that require thermal resistance, especially glass and ceramics. According to TGA data, the total mass loss of $\mathrm{HAp} / \mathrm{B}_{1}-\mathrm{HAp}_{\mathrm{B}} \mathrm{B}_{5}$ between $20-1150{ }^{\circ} \mathrm{C}$ was $0.446 \%, \% .433 \%, 2.426 \%, 3.235 \%$, and $1.184 \%$, respectively. The first mass loss seen in the region of $200-700{ }^{\circ} \mathrm{C}$ is due to the removal of lattice bound water [53]. In this temperature range, the highest mass loss occurred at h4, while the lowest mass loss occurred at HAp/B $\mathrm{B}_{2}$. Mass loss rates from small to large were $0.087 \%, 0.133 \%, 0.294 \%, 0.907 \%$, and $1.237 \%$ for $\mathrm{HAp} / \mathrm{B}_{2}, \mathrm{HAp} / \mathrm{B}_{1}, \mathrm{HAp} / \mathrm{B}_{5}, \mathrm{HAp} / \mathrm{B}_{3}$, and $\mathrm{HAp} / \mathrm{B}_{4}$, respectively.

According to the mass loss rates between $700-1150{ }^{\circ} \mathrm{C}$, the order from small to large was $\mathrm{HAp} / \mathrm{B}_{1}$, $\mathrm{HAp} / \mathrm{B}_{2}, \mathrm{HAp} / \mathrm{B}_{5}, \mathrm{HAp} / \mathrm{B}_{3}$ and $\mathrm{HAp} / \mathrm{B}_{4}(0.100 \%, 0.385 \%, 0.522 \%, 0.622 \%$, and $0.975 \%)$. The reason for the loss of mass in this region is the conversion of $\mathrm{HPO}_{4}{ }^{2-}$ to pyrophosphate $\left(\mathrm{P}_{2} \mathrm{O}_{7}{ }^{4-}\right)$ in HAp powders.

\section{Conclusions}


In the first stage of this study, a new polymer containing $B$ was synthesized. This new compound contributed to the formation of both $\mathrm{B}_{4} \mathrm{C}$ and $\mathrm{B}_{6} \mathrm{O}$ in the structure of hydroxyapatite. In the second stage, new hydroxyapatite powders were obtained by sol-gel method using compounds containing $\mathrm{Cu}$ and $\mathrm{Zn}$. Thus, five compounds with different morphology were obtained during the formation of hydroxyapatite. Especially the fact that $H A p / B_{1}$ and $H A p / B_{2}$ powders formed porous structures of different sizes showed that when applied to bone tissue, damaged tissue can heal in a short time.

Different spectroscopic methods were used for the characterization of the synthesized compounds and the data obtained proved that the targeted compounds were obtained. Especially, as a result of the thermogravimetric analysis, it was observed that their resistance to heat was high. $\mathrm{HAp} / \mathrm{B}_{4}$ had the highest heat resistance among the synthesized compounds. As a result of the heat treatment applied up to $1100{ }^{\circ} \mathrm{C}$, only $2.21 \%$ of the structure was degraded and separated. The main reason for this is the different rates of metal content in the structure.

\section{References}

1. Taş A.C., Korkusuz F., Timuçin M., Akkaş N., An invesligalion ol the chemical synthesis and hightemperature sintering behaviour of ealeium hydroxyapatite and tricaleium phosphate bioeeramics. $J$ Mat Sci Mat Med. 8 (1997) 91-96.

2. Korkusuz F., Tomin E., Yetkinler D.N., Timuçin M., Öztürk A., Korkusuz P., Synthetic bone grafts . TOTBID journal 10 (2011) 134-142.

3. Taş A.C., Korkusuz F., Timuçin M., Akkaş N., An investigation of the chemical synthesis and hightemperature sintering behaviour of calcium hydroxyapatite $(\mathrm{HA})$ and tricalcium phosphate (TCP) bioceramics. J Mater Sci Mater Med., 8 (1997) 91-6.

4. Koç N., Timuçin M., Korkusuz F., Fabrication and characterization of porous hydroxyapatite and biphasic calcium phosphate ceramic as bone substitutes. Key Eng. Mat., 254 (2004) 949-952.

5. Koç N., Timuçin M., Korkusuz F., Fabrication and characterization of porous tricalcium phosphate ceramics. Ceramics Int., 30 (2004) 205-211.

6. Balçik C., Tokdemir T., Senköylü A., Koç N., Timuçin M., Akin S., Korkusuz P., Korkusuz F., Early weight bearing of porous HA/TCP $(60 / 40)$ ceramics in vivo: A longitudinal study in a segmental bone defect model of rabbit. Acta Biomater, 3 (2007) 985-996.

7. Kulanthaivel, S., Mishra, U., Agarwal, T., Giri, S., Pal, K., Pramanik, K., Banerjee, I., Improving the osteogenic and angiogenic properties of synthetic hydroxyapatite by dual doping of bivalent cobalt and magnesium ion, Ceramics International, 41 (2015) 11323-11333.

8. Masoudi Rad, M., Nouri Khorasani, S., Ghasemi-Mobarakeh, L., Prabhakaran, M.P., Foroughi, M.R., Kharaziha, M., Saadatkish, N., Ramakrishna, S., Fabrication and characterization of two-layered nanofibrous membrane for guided bone and tissue regeneration application, Materials Science and Engineering: C, 80 (2017) 75-87. 
9. Mazón, P., De Aza, P.N., Porous scaffold prepared from a'L-Dicalcium silicate doped with phosphorus for bone grafts, Ceramics International, 44 (2018) 537-545.

10. Siek, D., Ślósarczyk, A., Przekora, A., Belcarz, A., Zima, A., Ginalska, G., Czechowska, J., Evaluation of antibacterial activity and cytocompatibility of a-TCP based bone cements with silver-doped hydroxyapatite and $\mathrm{CaCO}_{3}$, Ceramics International, 43 (2017) 13997-14007.

11. Youness, R.A., Taha, M.A., Ibrahim, M.A., Effect of sintering temperatures on the in vitro bioactivity, molecular structure and mechanical properties of titanium/carbonated hydroxyapatite nanobiocomposites, Journal of Molecular Structure, 1150 (2017) 188-195.

12. Sartori, T.A.I.D.C., Ferreira, J.A., Osiro, D., Colnago, L.A., Pallone, E.M.D.J.A., Formation of different calcium phosphate phases on the surface of porous $\mathrm{Al}_{2} \mathrm{O}_{3}-\mathrm{ZrO}_{2}$ nanocomposites, Journal of the European Ceramic Society, 38 (2018) 743-751.

13. Kaygili, O., Keser, S., Ates, T., Al-Ghamdi, A.A., Yakuphanoglu, F., Controlling of dielectrical and optical properties of hydroxyapatite based bioceramics by Cd content, Powder Technology, 245 (2013) 1-6.

14. Kong L.B., Ma J., Boey F., Nanosized hydroxyapatite powders derived from coprecipitation process, J.Mater. Sci., 37 (2002) 1131-1134.

15. Kumta P.N., Sfeir C., Lee D.H., Olton D., Choi D., Nanostructured calcium phosphates for biomedical applications: novel synthesis and characterization, Acta Biomater., 1 (2005), 65-83.

16. Sung Y.M., Lee J.C., Yang J., Crystallization and sintering characteristics of chemically precipitated hydroxyapatite nanopowder, Journal of Crystal Growth, 262 (2004) 467-472.

17. Jalota S., Tas C., Bhaduri S.B., Microwave-assisted synthesis of calcium phosphate nanowhiskers, J. Mater. Res., 19 (2004) 1876-1881.

18. Fihri, A., Len, C., Varma, R.S., Solhy, A., Hydroxyapatite: A review of syntheses, structure and applications in heterogeneous catalysis, Coordination Chemistry Reviews, 347 (2017) 48-76.

19. Harun, W.S.W., Asri, R.I.M., Alias, J., Zulkifli, F.H., Kadirgama, K., Ghani, S.A.C., Shariffuddin, J.H.M., A comprehensive review of hydroxyapatite-based coatings adhesion on metallic biomaterials, Ceramics International, 44 (2 018)1250-1268.

20. Rahmati, M., Fathi, M., Ahmadian, M., Preparation and structural characterization of bioactive bredigite (Ca7MgSi4016) nanopowder, Journal of Alloys and Compounds, 732 (2018) 9-15.

21. Kaygili, O., Tatar, C., Yakuphanoglu, F., Structural and dielectrical properties of $\mathrm{Mg}_{3}-\mathrm{Ca}_{3}\left(\mathrm{PO}_{4}\right)_{2}$ bioceramics obtained from hydroxyapatite by sol-gel method, Ceramics International, 38 (2012) 5713-5722.

22. Kaygili, O., Ates, T., Keser, S., Al-Ghamdi, A., Yakuphanoglu, F., Controlling of dielectrical properties of hydroxyapatite by ethylenediamine tetraacetic acid (EDTA) for bone healing applications, Spectrochimica Acta Part A: Molecular and Biomolecular Spectroscopy, 129 (2014) 268-273.

23. Kaygili, O., Keser, S., Ates, T., Yakuphanoglu, F., Synthesis and characterization of lithium calcium phosphate ceramics, Ceramics International, 39 (2013) 7779-7785. 
24. Kaygili, O., Keser, S., Al Orainy, R.H., Ates, T., Yakuphanoglu, F., In vitro characterization of polyvinyl alcohol assisted hydroxyapatite derived by sol-gel method, Materials Science and Engineering: C, 35 (2014) 239-244.

25. Fathyunes, L., Khalil-Allafi, J., Effect of employing ultrasonic waves during pulse electrochemical deposition on the characteristics and biocompatibility of calcium phosphate coatings, Ultrasonics Sonochemistry, 42 (2018) 293-302.

26. Tao, J., Jiang, W., Pan, H., Xu, X., Tang, R., Preparation of large-sized hydroxyapatite single crystals using homogeneous releasing controls, Journal of Crystal Growth, 308 (2007) 151-158.

27. Vallet-Regí, M., González-Calbet, J.M., Calcium phosphates as substitution of bone tissues, Progress in Solid State Chemistry, 32 (2004) 1-31.

28. Tomoda, K., Ariizumi, H., Nakaji, T., Makino, K., Hydroxyapatite particles as drug carriers for proteins, Colloids and Surfaces B: Biointerfaces, 76 (2010) 226-235.

29. Afshar A., Ghorbani M., Ehsani N., Sorrell C., Saeri M.R., Some important factors in the wet precipitation process of hydroxyapatite, Materials and Design, 24, (2003), 197-202.

30. Saeri M.R., Afshar A., Ghorbani M., Ehsani N., Sorrell C., The wet precipitation process of hydroxyapatite, Materials Letters, 57, (2003), 4064-4069.

31. Evis Z., High temperature sintering of $\mathrm{Cu}^{+2}$ doped hydroxyapatites and microstructural investigation, Journal of the Faculty of Engineering and Architecture of Gazi University, 24 (2009), 569-573.

32. Ipekoglu M., Altintas S., Silver substituted nanosized calcium deficient hydroxyapatite, Materials Technology: Advanced Performance Materials, 25 (2010), 295-301.

33. Cox S.C., Jamshidi P., Grover L.M., Mallick K.K., Preparation and characterization of nanophase Sr, Mg, and Zn substituted hydroxyapatite by aqueous precipitation, Mater. Sci. Eng., C, 35 (2014) 106114.

34. Hakki S.S., Boron regulates mineralized tissueassociated proteins in osteoblasts, J. Trace Elem. Med.Biol., 24 (2010) 243-250.

35. Çanakçı D., Synthesis, spectroscopic, thermodynamics and kinetics analysis study of novel polymers containing various azo chromophore, Scientific Reports 10 (2020) 477.

36. Puroniene G.I., Zarkov A., Tsuru K., Ishikawa K., Kareiva A., A novel synthetic approach for the calcium hydroxyapatite from the food products, Journal of Sol-Gel Science and Technology, 91 (2019) 63-71.

37. Cimdina L.B., Borodajenko N., Research of calcium phosphates using fourier transform infrared spectroscopy, Infrared Spectroscopy - Materials Science, Engineering and Technology, (2012).

\section{Table}

Table 1. The average particle size, fraction of crystalline phase and specific surface area of HAp/B $B_{1-5}$ 


\begin{tabular}{|llll|}
\hline Sample & $D^{*}(\mathrm{~nm})$ & $\mathrm{X}_{\mathrm{c}}[\%]$ & $\mathrm{S}_{\mathrm{sp}}\left[\mathrm{m}^{2} / \mathrm{g}\right]$ \\
\hline HAp/B & 88 & 98 & 21.57 \\
\hline HAp/B & 69 & 99 & 27.51 \\
\hline HAp/B & 95 & 97 & 19.98 \\
\hline HAp/B & 84 & 97 & 22.60 \\
\hline HAp/B $_{5}$ & 70 & 93 & 27.12 \\
\hline
\end{tabular}

Figures

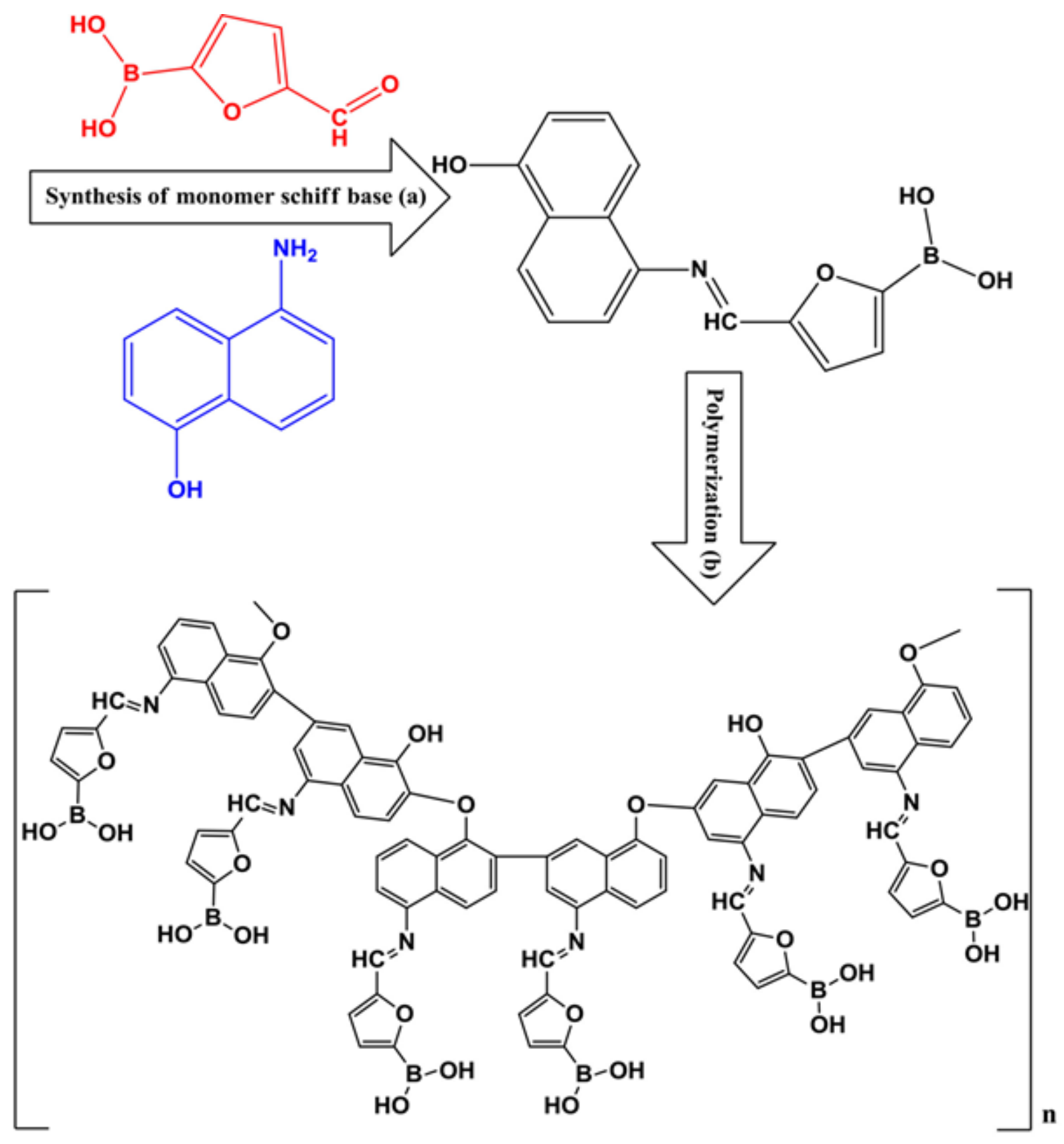


Figure 1

Synthesis of monomer schiff base (a) and polymer schiff base (b)

\begin{tabular}{|c|}
\hline $\begin{array}{l}-\mathrm{Ca}\left(\mathrm{NO}_{3}\right)_{2} \cdot 4 \mathrm{H}_{2} \mathrm{O}, \mathrm{Ca}\left(\mathrm{NO}_{3}\right)_{2} \cdot 4 \mathrm{H}_{2} \mathrm{O}, \mathrm{KH}_{2} \mathrm{PO}_{4} \text { and } \\
\text { NaHCO } \\
\end{array}$ \\
\hline $\begin{array}{l}\text { - } \mathrm{PSB}, \mathrm{Cu}\left(\mathrm{CH}_{3} \mathrm{CO}_{2}\right)_{2} \text { and } \mathrm{Zn}\left(\mathrm{CH}_{3} \mathrm{CO}_{2}\right)_{2} \text { in different } \\
\text { proportions were added into the formed solution }\end{array}$ \\
\hline - $\mathrm{P}_{4} \mathrm{O}_{10}$ was added in to the homogeneous solution \\
\hline - $\mathrm{pH}$ adjustment \\
\hline $\begin{array}{l}\text { - Refluxing at room temperature for } 1 \text { hour and then } \\
50^{\circ} \mathrm{C} \text { for } 1 \text { hour }\end{array}$ \\
\hline - Drying in the oven at $105^{\circ} \mathrm{C}$ for 12 hours \\
\hline - Calcining at $1100^{\circ} \mathrm{C}$ for 3 hours \\
\hline
\end{tabular}

Figure 2

Preparation of novel metal doped HAp by sol-gel method.

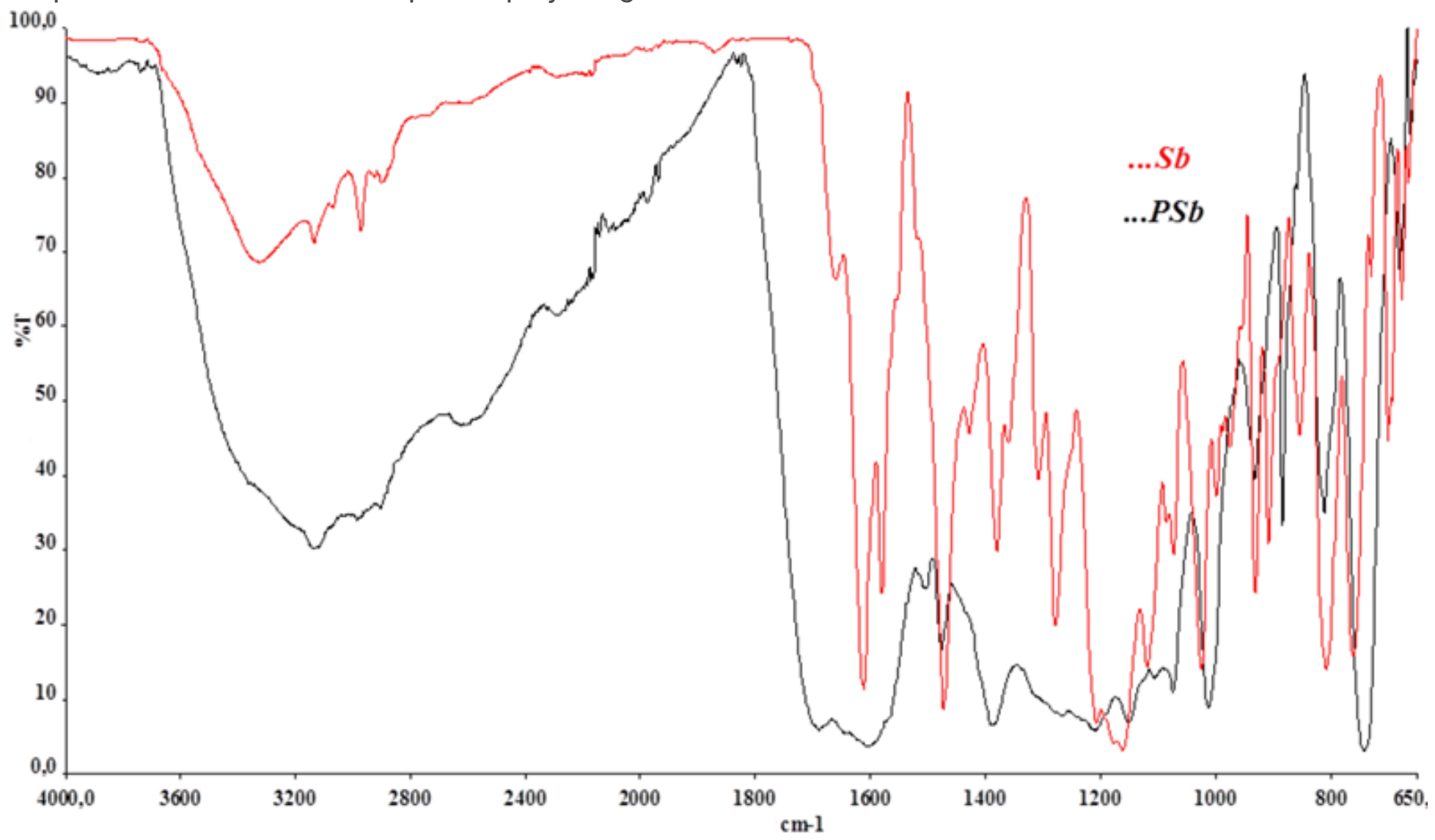


Figure 3

FT-IR spectrum of Sb and PSb.

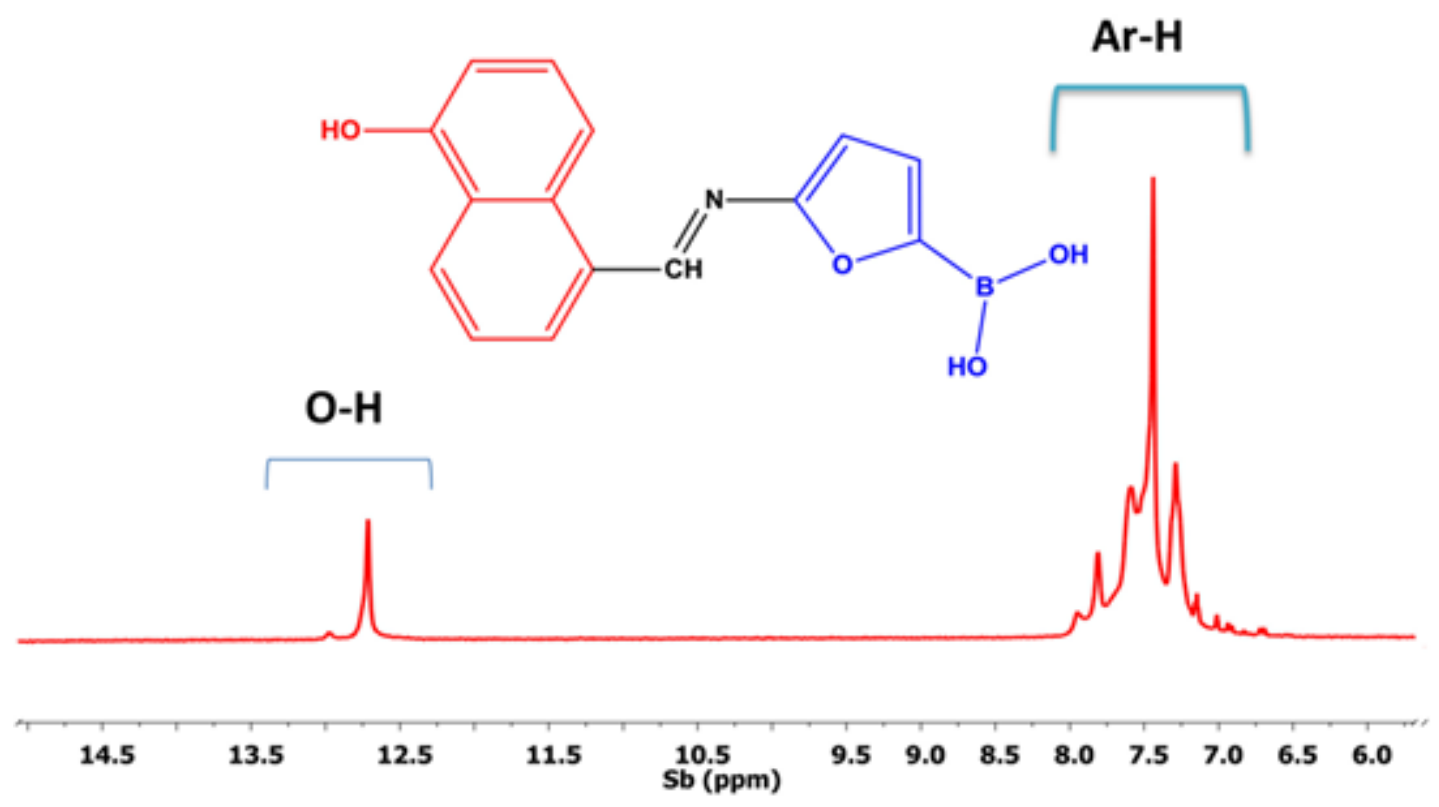

Figure 4

1H-NMR spectrum of Sb.
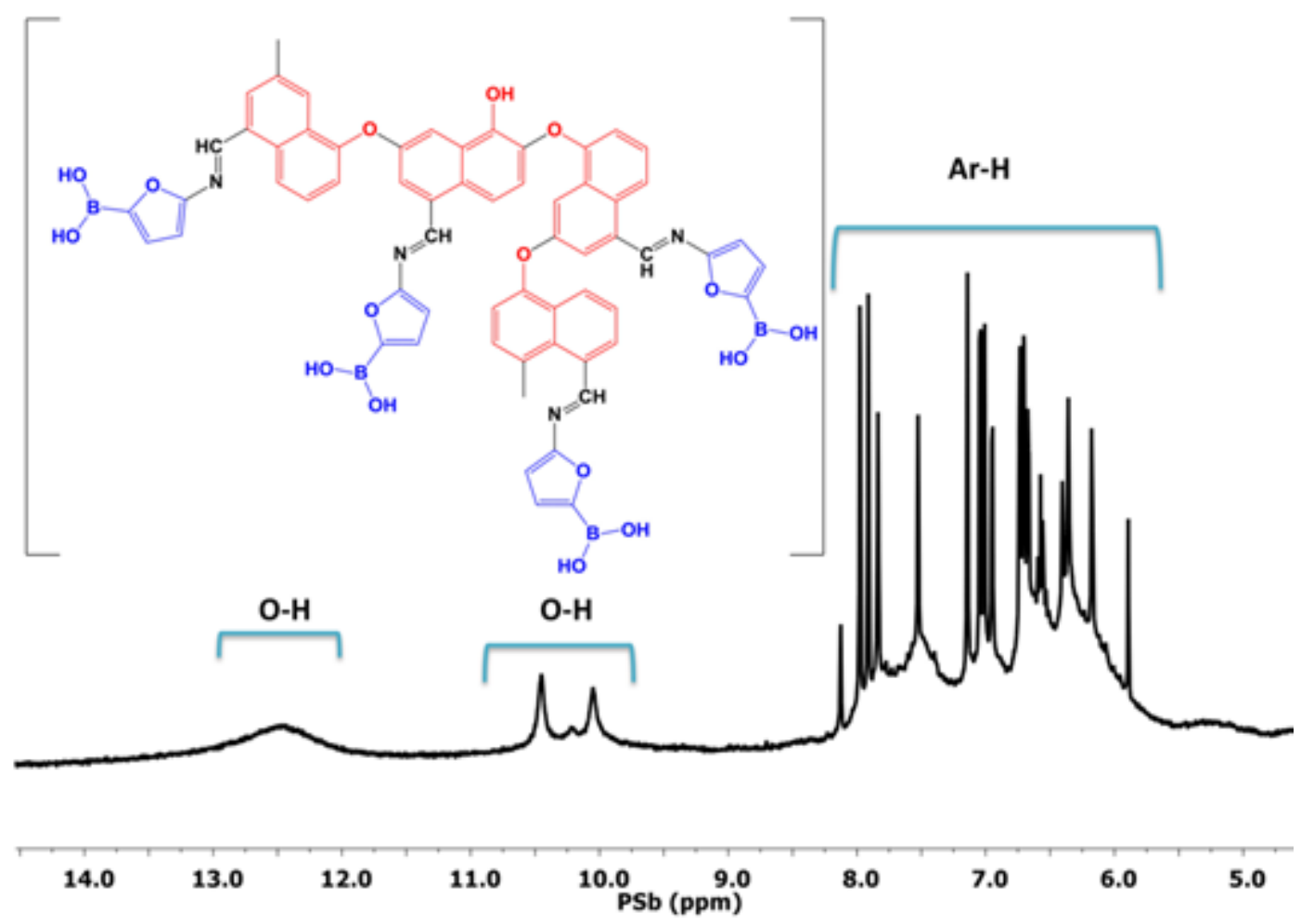

Figure 5

1H-NMR spectrum of PSb. 


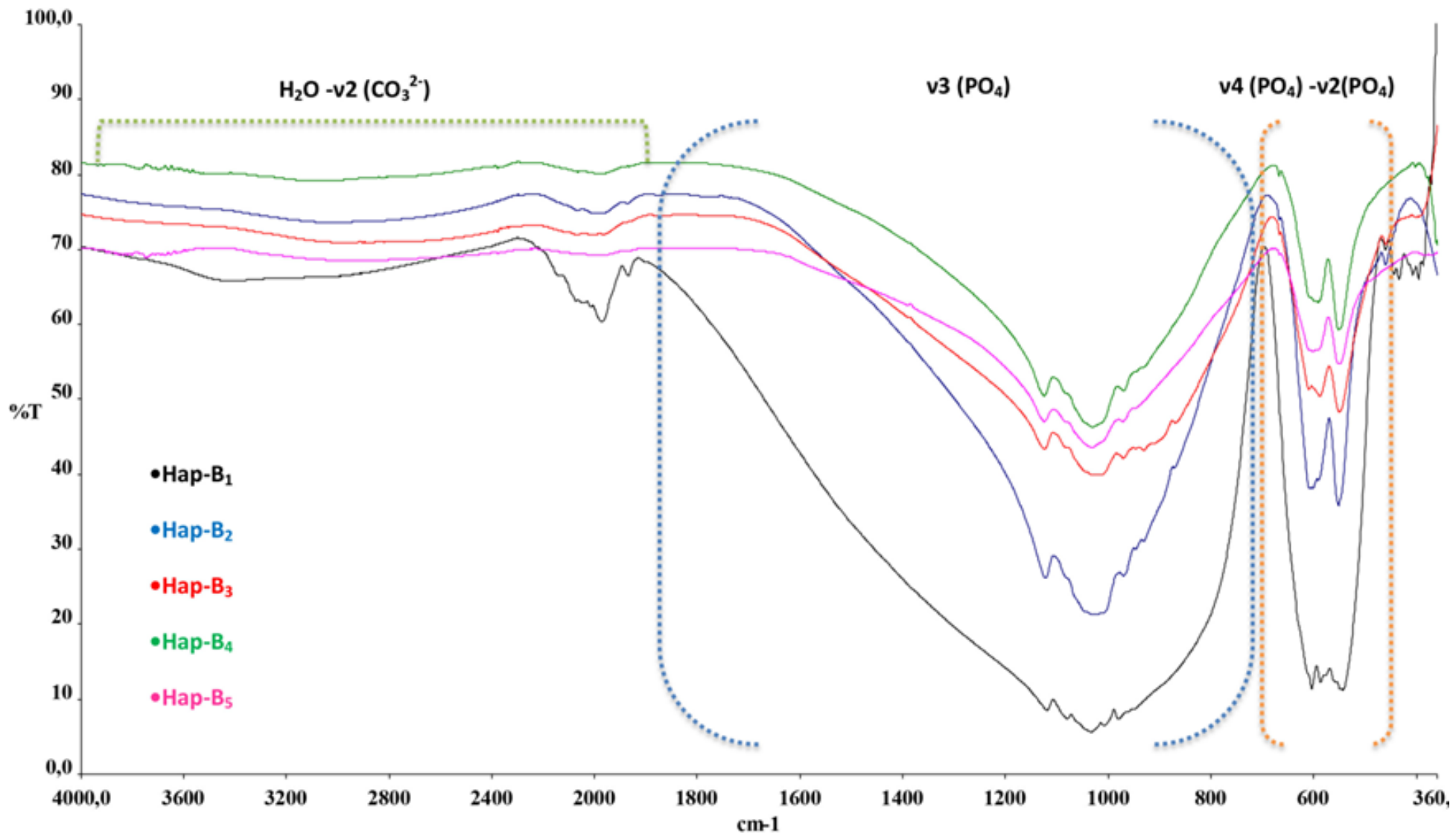

Figure 6

FT-IR spectrum of HAp-B1, HAp-B2, HAp-B3, HAp-B4 and HAp-B5.

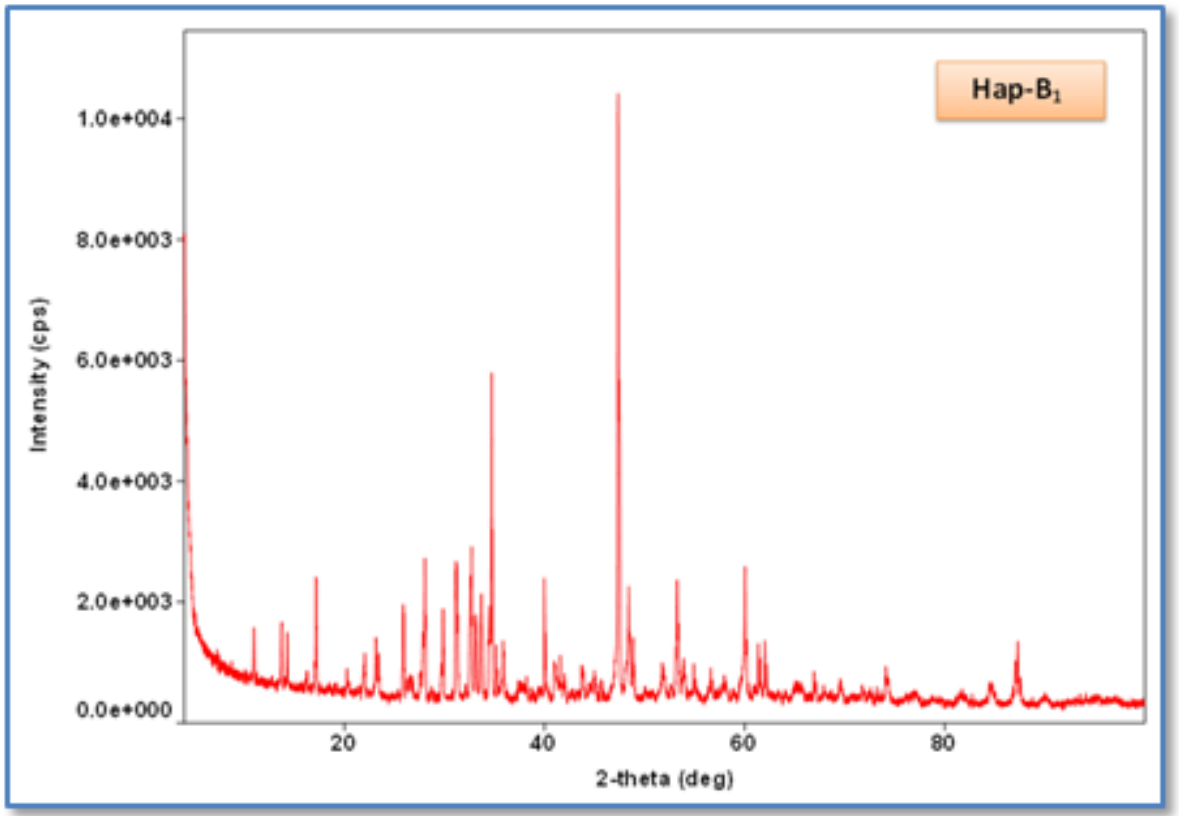

Figure 7

X-ray diffractogram of novel metal doped HAp (HAp-B1). 

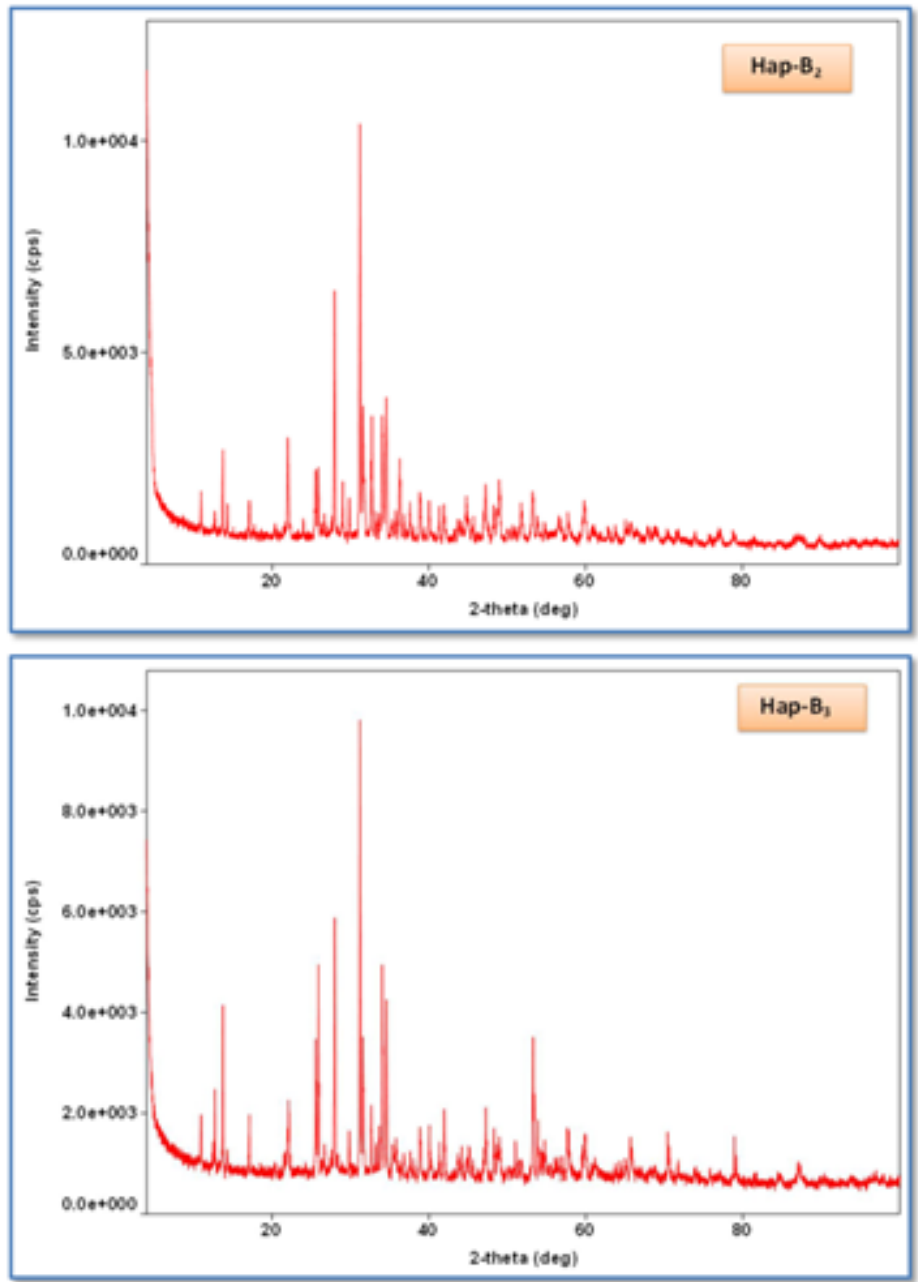

Figure 8

X-ray diffractograms of novel metal doped HAp (HAp-B2 and HAp-B3). 

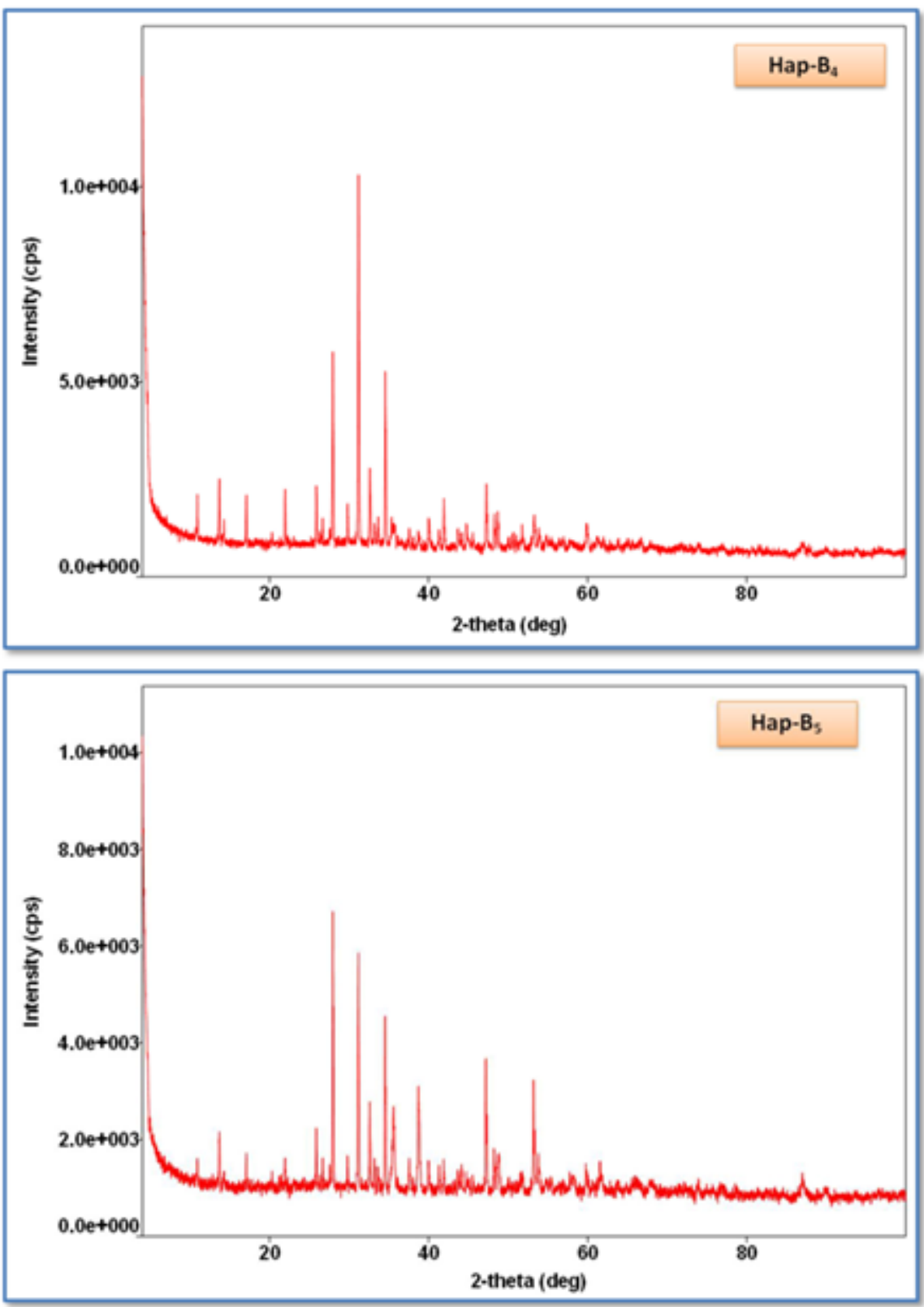

Figure 9

X-ray diffractograms of novel metal doped HAp (HAp-B4 and HAp-B5). 

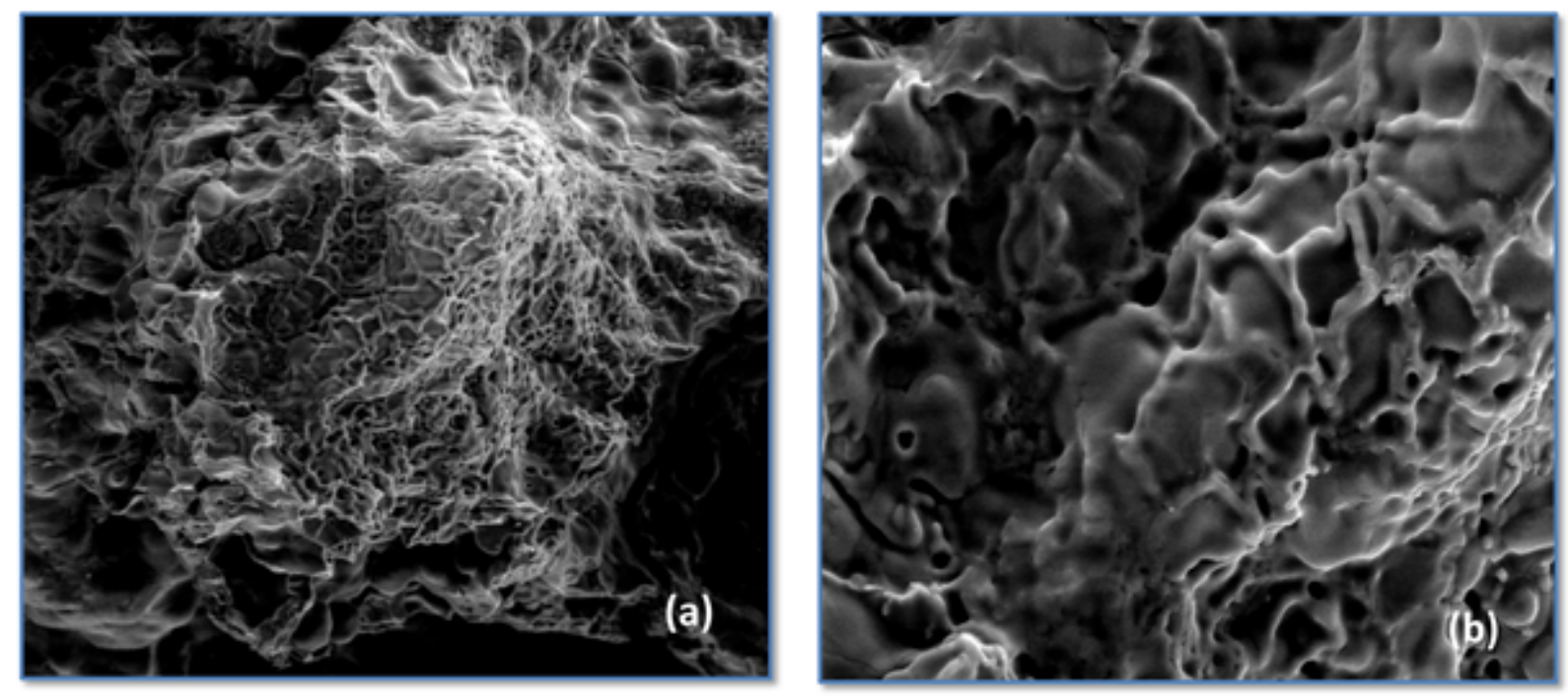

Figure 10

Scanning electron microscopy image of HAp-B1 under 20kV (500x-2000x) 

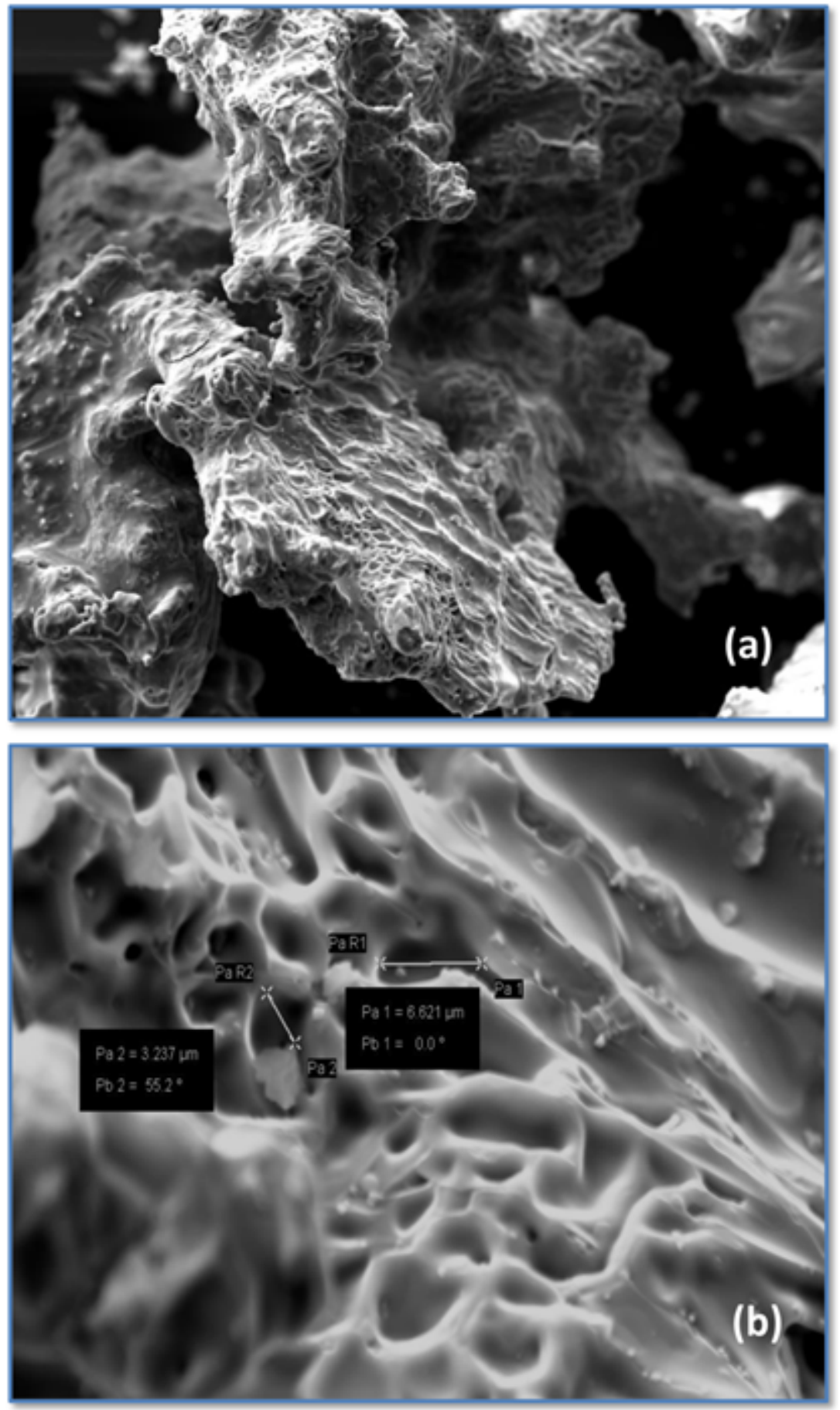

\section{Figure 11}

Scanning electron microscopy image of HAp-B2 under 20kV (500x-50.000x) 


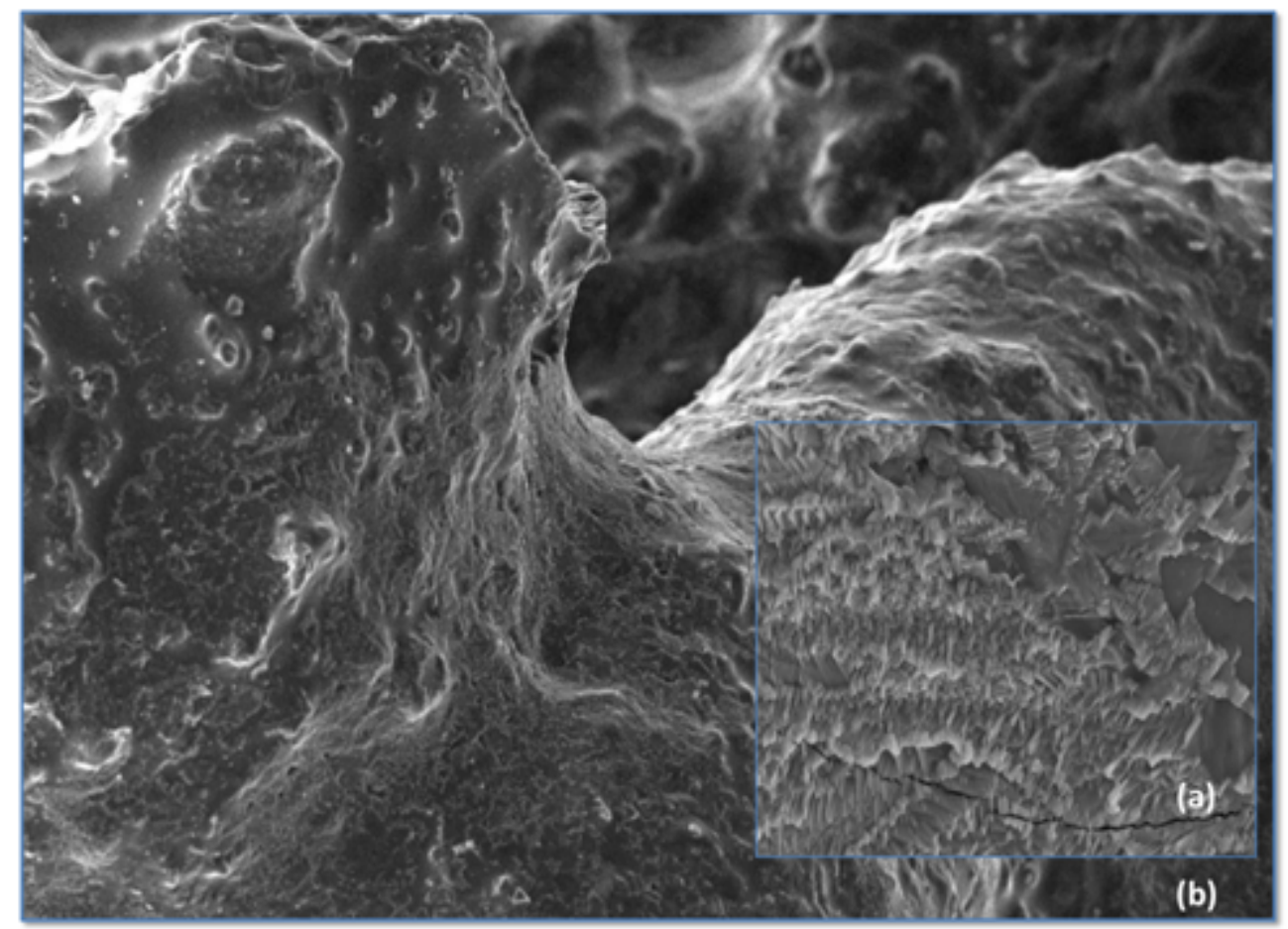

Figure 12

Scanning electron microscopy image of HAp-B3 under 20kV (2.000x-10.000x)

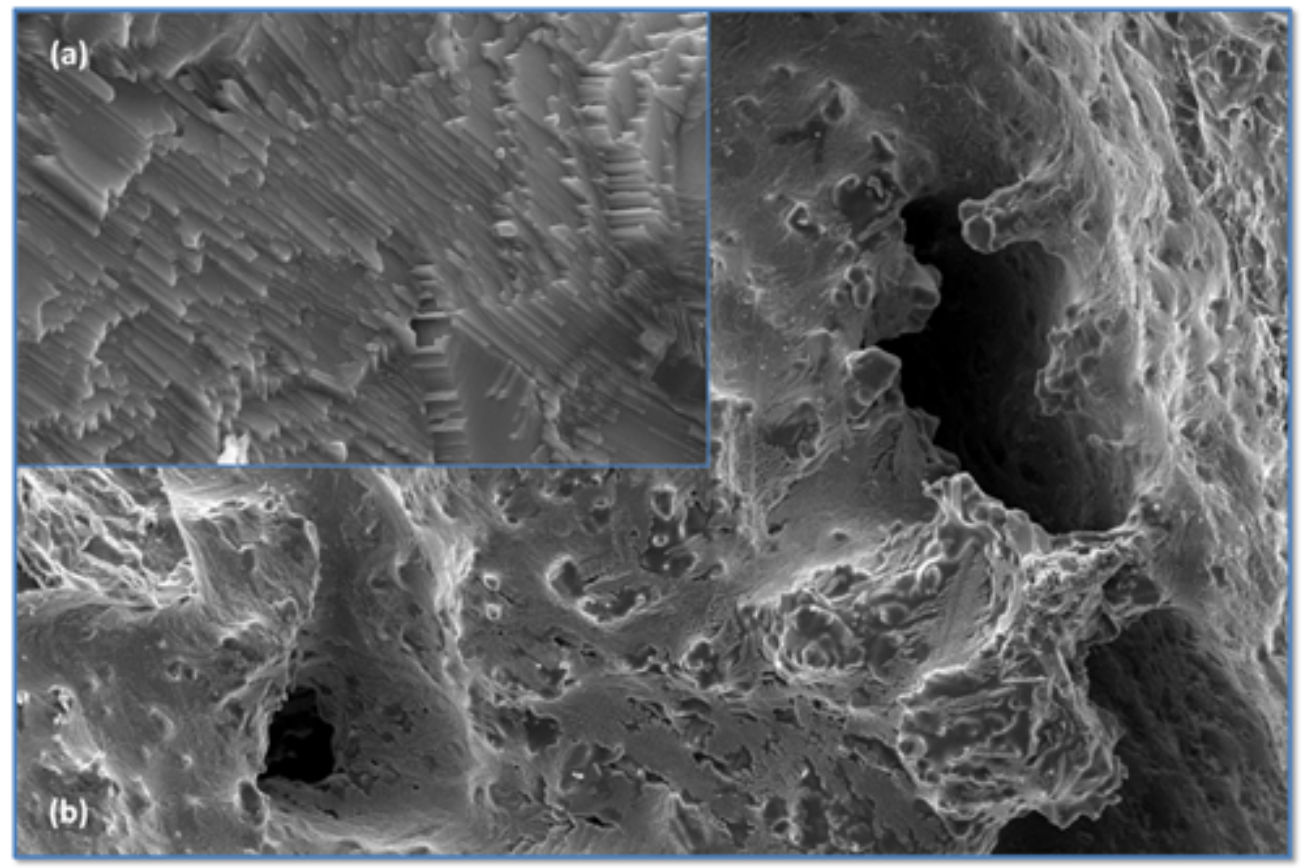

\section{Figure 13}

Scanning electron microscopy image of HAp-B4 under 20kV (500x-10.000x) 


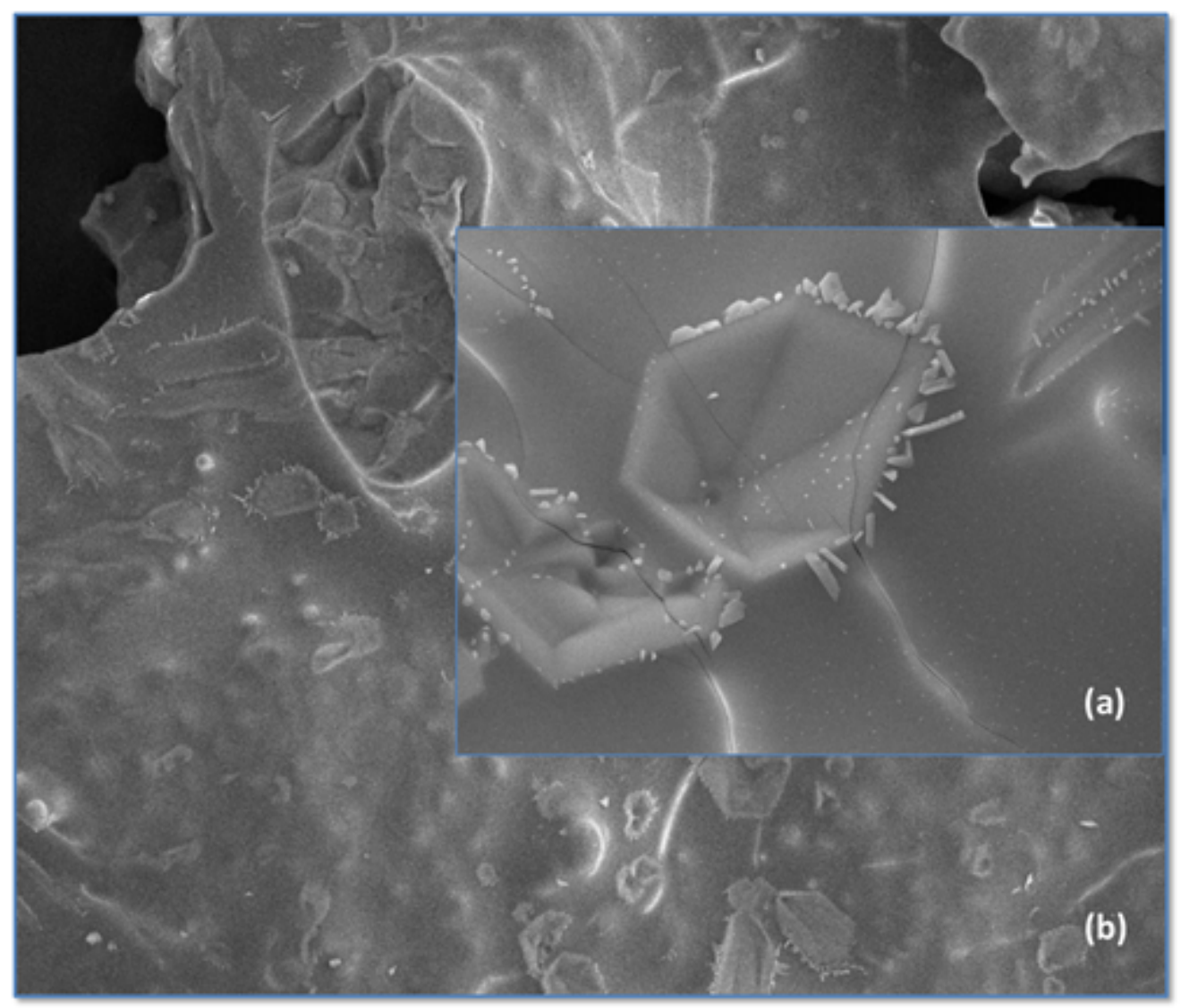

Figure 14

Scanning electron microscopy image of HAp-B5 under 20kV (500x-10.000x) 

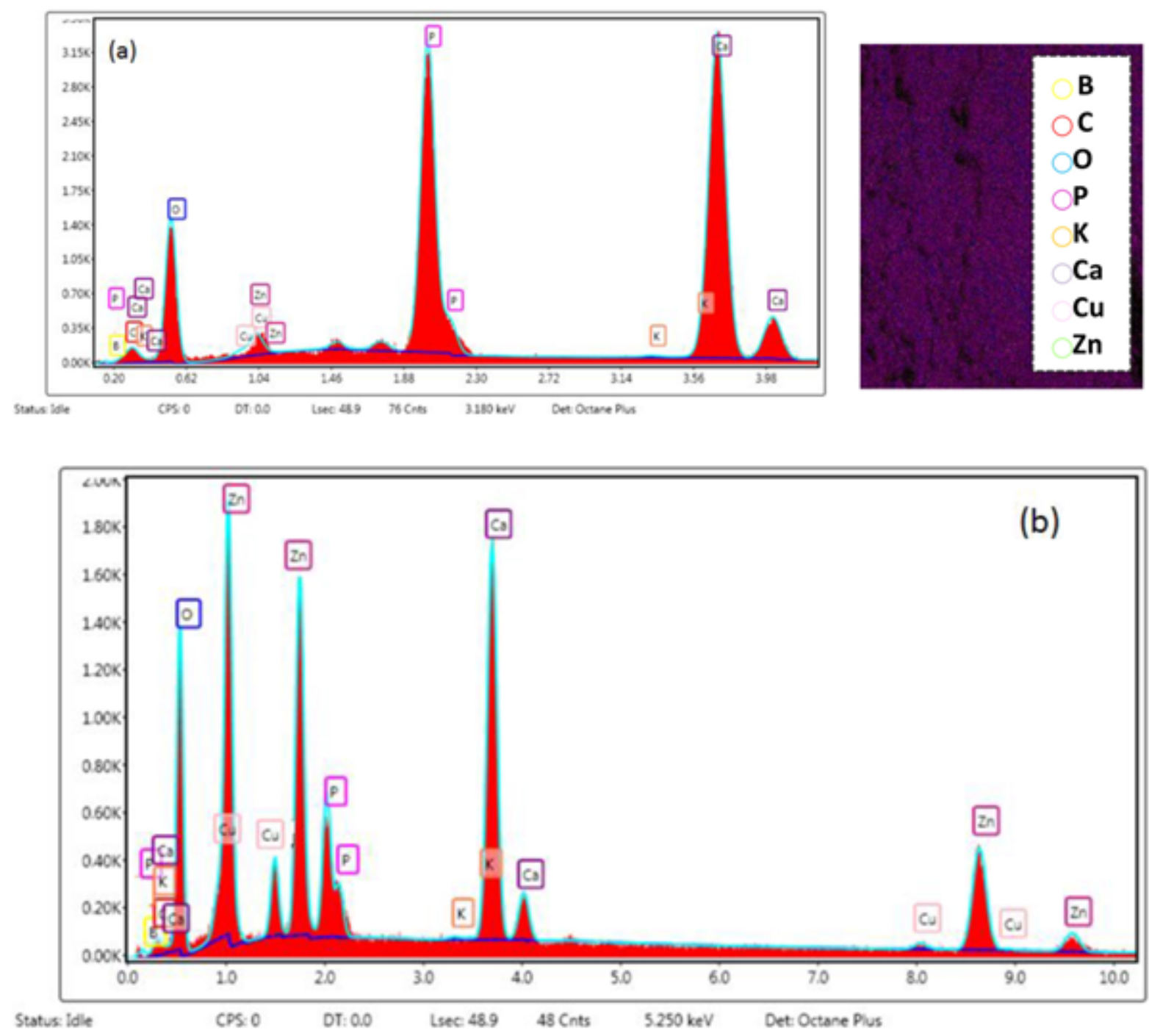

Figure 15

EDX spectra of novel metal doped HAp: (a) HAp-B1; (b) HAp-B2 

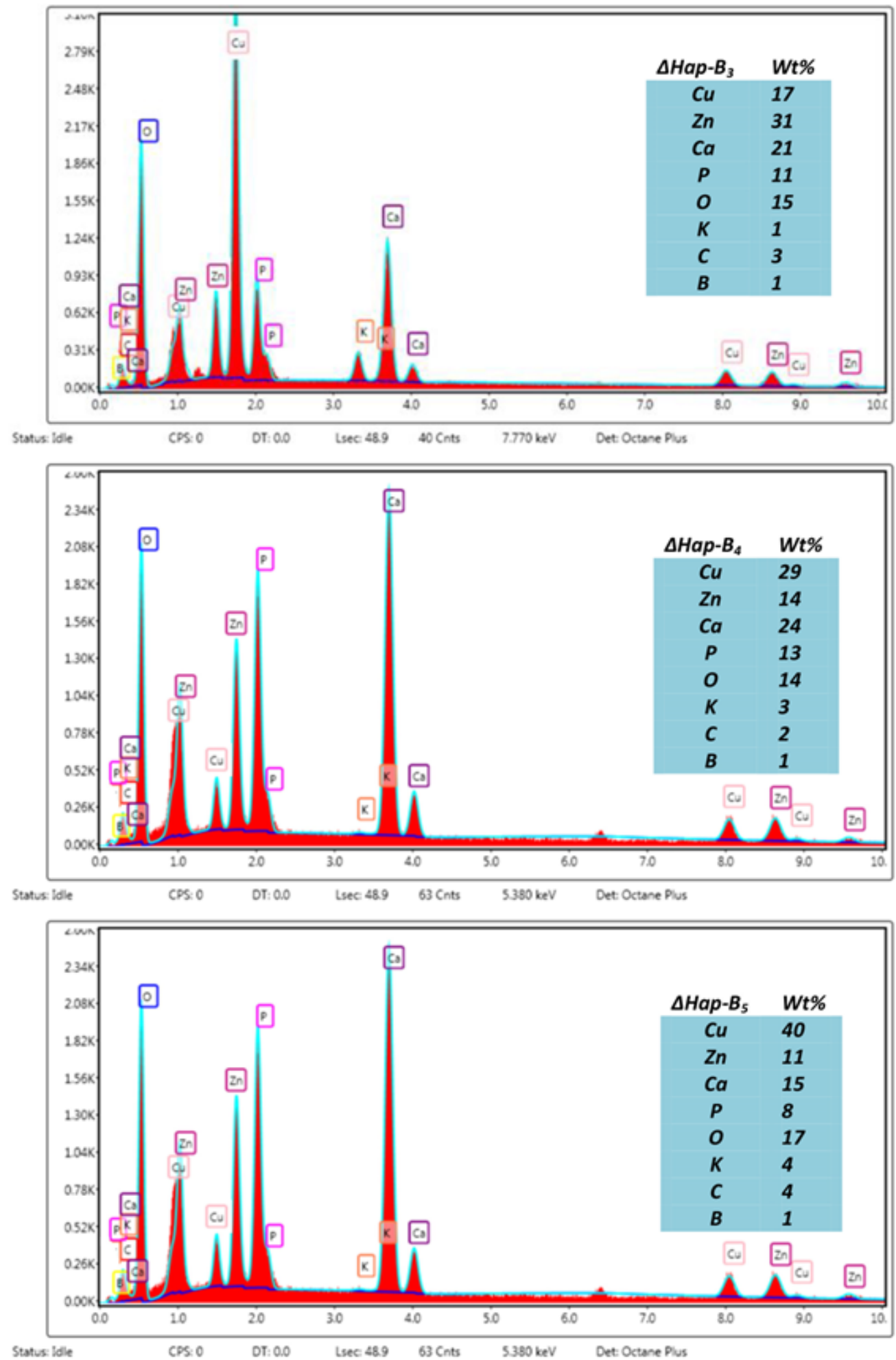

Figure 16

EDX spectra of novel metal doped HAp (HAp-B3, HAp-B4, HAp-B5). 


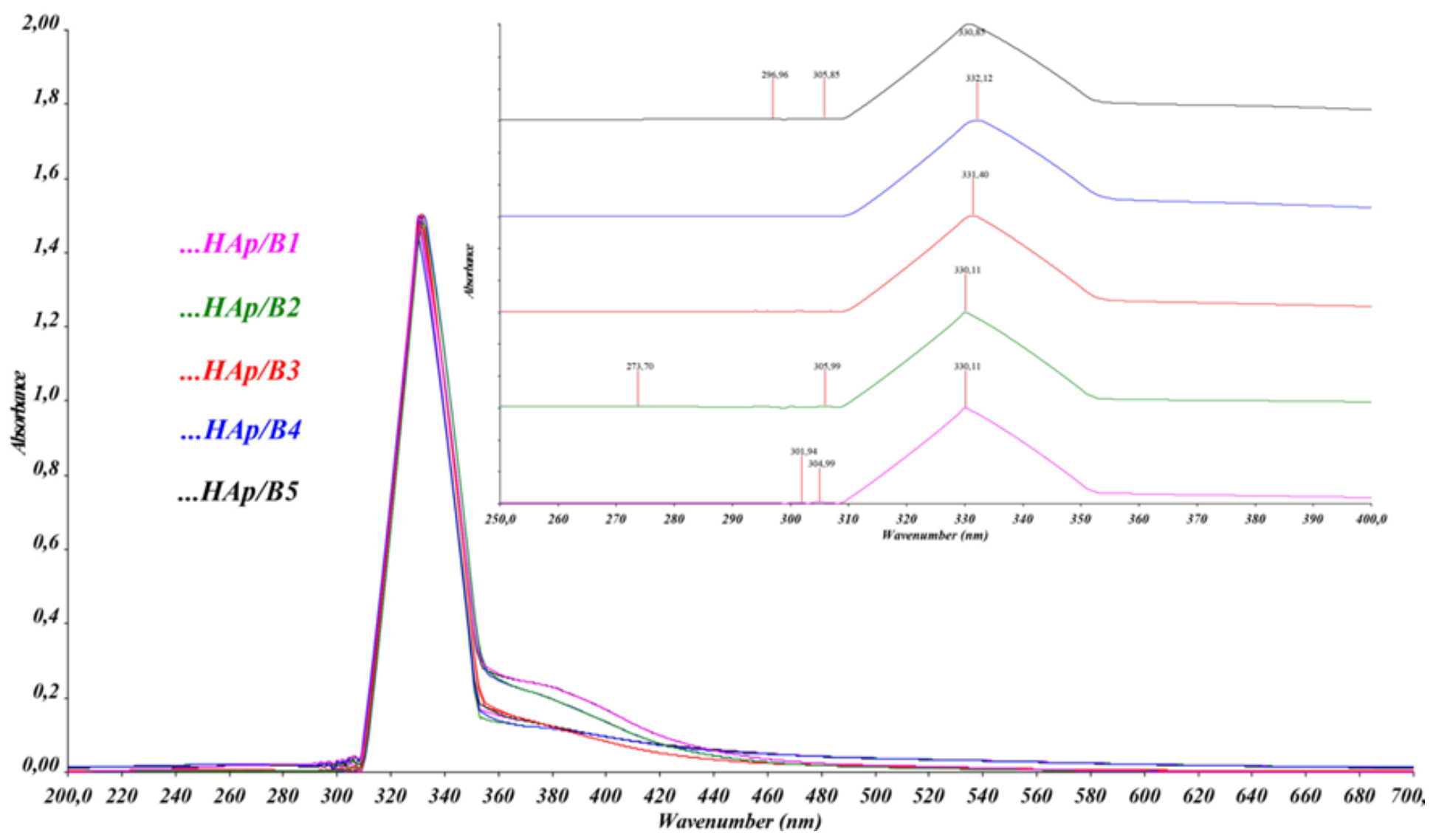

Figure 17

UV-vis spectra of HAp-B1, HAp-B2, HAp-B3, HAp-B4 and HAp-B5 


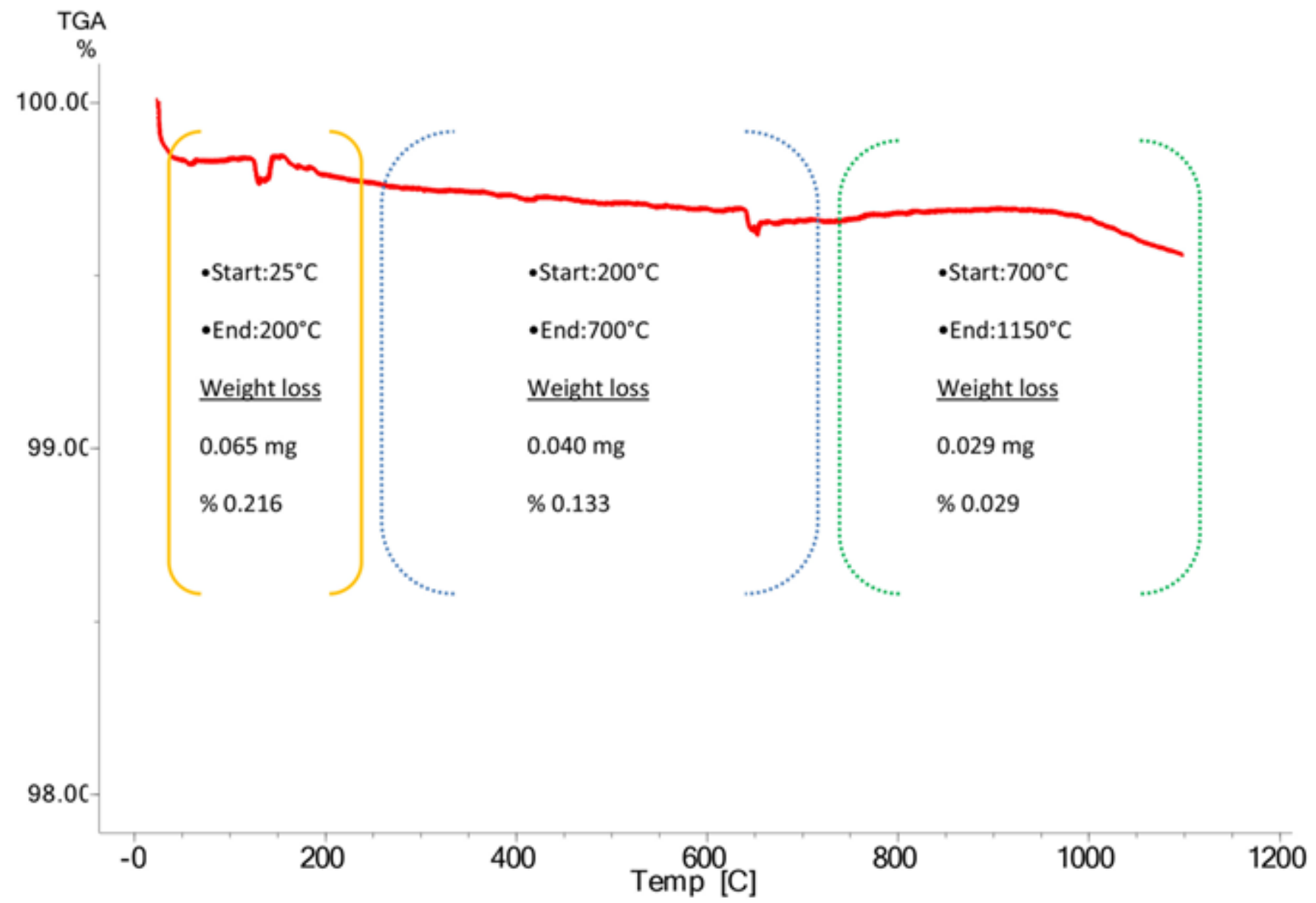

Figure 18

TG curve of HAp-B1 


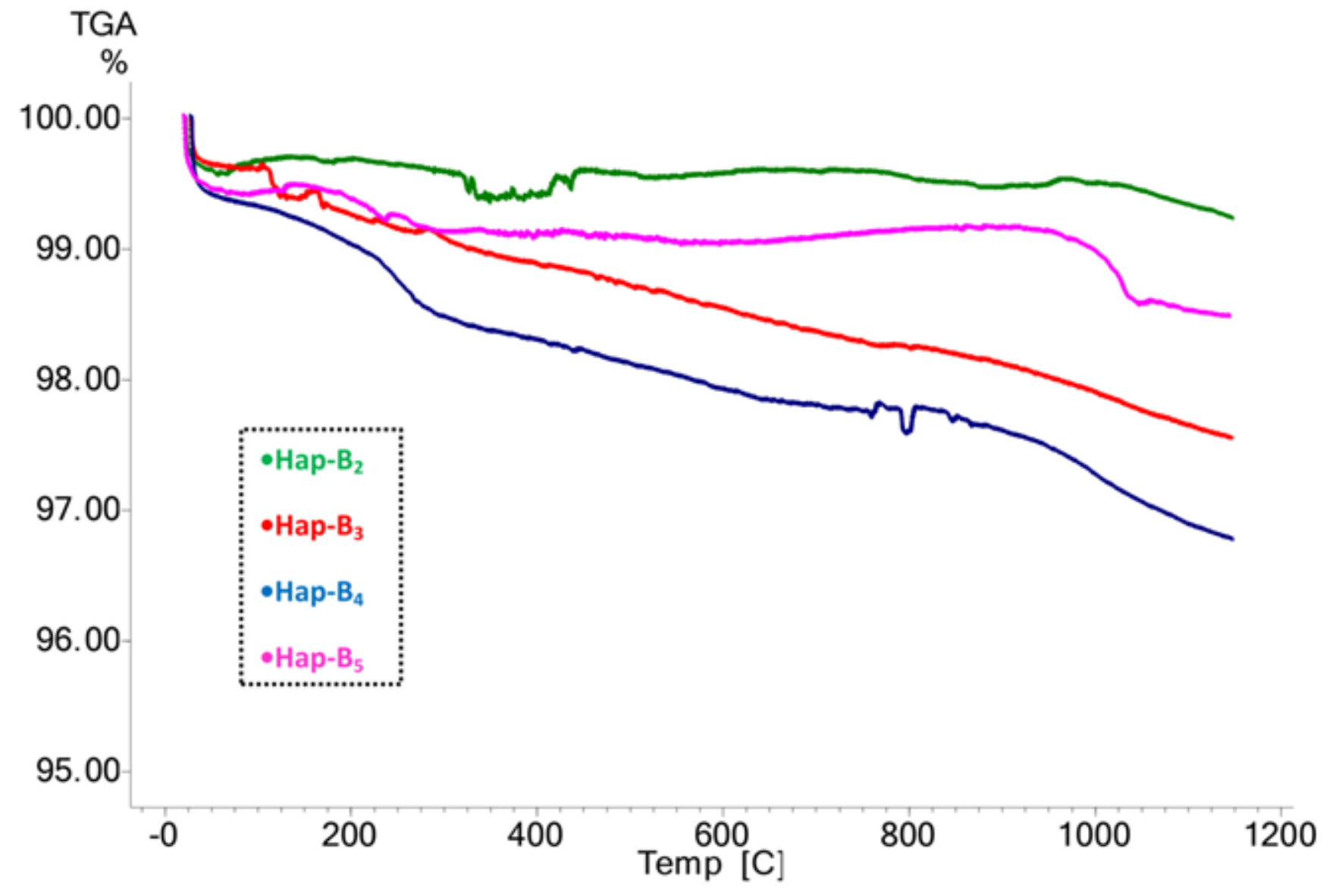

Figure 19

TG curve of HAp-B2, HAp-B3, HAp-B4 and HAp-B5 